\title{
Property attribution of 3D geological models in the Thames Gateway, London : new ways of visualising geoscientific information
}

\author{
K.R. ROYSE (D) \\ H.K. RUTTER \\ D.C. ENTWISLE
}

British Geological Survey, Kingsley Dunham Centre, Keyworth, Nottingham, UK

Email: krro@bgs.ac.uk

Tel: +44-115-9363456

FAX: +44-115-9363593

Abstract

Rapid developments in information technology and the increasing collection and digitisation of geological data by the British Geological Survey now allow geoscientists to produce meaningful 3D spatial models of the shallow subsurface in many urban areas. Using this new technology, it is possible to model and predict not only the type of rocks in the shallow subsurface, but also their engineering properties (rock strength, shrink-swell characteristics and compressibility) and hydrogeological properties (permeability, porosity, thickness of the unsaturated zone or the likelihood of perched water tables) by attribution of the 3D model with geological property data. This paper describes the hydrogeological, engineering and confidence (uncertainty) attribution of high resolution models of the Thames Gateway Development Zone (TGDZ) east of London UK and proposes a future in which site investigation sets out to test a pre-existing spatial model based on real data rather than a conceptual model.

Keywords 3D modelling decision making Sition Investigation 


\section{Introduction}

The importance of good quality geo-environmental information is becoming increasingly important as legislative changes [e.g. in the UK, Planning Policy statement (PPS) 9, 23 and 25 (Communities and Local Government 2006 a \& b, and ODPM 2004) and Part IIA of the Environment Protection Act, 1990] have forced developers, to consider the implications and impact of large-scale development initiatives on the environment. To comply with the principles of sustainable development, developers are required to demonstrate that proposals are based on the best possible scientific information and analysis of risk. Therefore, increasingly, organisations involved in planning and development are now requiring access to geoscientific information in the past. Many of these organisations have not made much use of geoscientific information and find the traditional geological map difficult to interpret.

Advances in three dimensional modelling technology are providing the geoscientist with innovative ways to present geoscientific information to planners, engineers and developers. It is now possible to view and manipulate 3D models on a standard desktop computer and, more importantly, the model can be updated quickly and easily when new data become available. These are major steps forward from previous 3D urban modelling systems (Strange et al. 1998), which required a significant amount of specialist computer knowledge and access to large computing capabilities. Data outputs also tended to be static, as updating was difficult and time-consuming.

This paper will show how it is possible to attribute the 3D geological model with a variety of information, including geotechnical, hydrogeological and confidence data. The resultant model can be used to predict the type of rocks present within a particular site, as well as the variation in their engineering properties (strength, shrink-swell characteristics and compressibility) and hydrogeological properties (permeability and porosity).

The research on which this paper is based focuses on London and the Thames Gateway Development Zone (TGDZ) but builds on earlier work in Manchester and Salford (Culshaw 2005, Lelliott et al. 2006). The TGDZ was chosen because a large proportion of planned development projects will necessitate construction on ground that contains compressible soils, 
high groundwater levels and potentially contaminated brownfield sites, for which knowledge of the geology is crucial if sound decisions are to be made.

\section{Geological setting}

The TGDZ is contained within the London Basin (Fig. 1). Geologically, the London Basin is a broad, gentle synclinal fold, whose axis can be traced from Marlborough through to Westminster. The London Basin formed in the Oligocene to mid- Miocene times during the main Alpine compressional event. Formations in this region range from Cretaceous (144 to 65 Ma) to Quaternary (2 Ma to present day) in age. The Cretaceous Chalk is typically a fine grained white limestone (Bristow et al.1997 provided a detailed description of the Chalk lithostratigraphy). It has a total thickness of between 175 and $200 \mathrm{~m}$ and generally thins from the West to the East.

\section{Fig. 1}

Overlying the Chalk is the oldest Palaeogene deposit, the Thanet Sand Formation. This Formation consists of a coarsening upwards sequence of fine-grained, grey sand. The formation reaches a maximum thickness of around $30 \mathrm{~m}$ in the area. A basal conglomerate (the Bullhead Beds) defines the base of the Thanet Sand, which consists of rounded black flint pebbles. Above the Thanet Sand Formation lies the Lambeth Group. This Group consists of three Formations: the Upnor, the Woolwich and the Reading Formations. The Lambeth Group is between 20 and $30 \mathrm{~m}$ thick in the area and lithologically is highly variable, consisting of differing proportions of sands, silts, clays and gravels.

Overlying this are the Eocene sediments of the Thames Group which consist of the Harwich and London Clay Formations. The Harwich Formation (formerly known as the Blackheath, or Oldhaven Beds) consists predominantly of sand and pebble beds up to $4 \mathrm{~m}$ thick. Above this is approximately 90 to $130 \mathrm{~m}$ of London Clay. The London Clay Formation consists of grey to blue grey, bioturbated, silty clay. Quaternary deposits are encountered right across the TGDZ. These include evidence of an ancient river system and the development of the present day River Thames valley. Deposits include alluvium, peat, brickearth (mostly wind blown sand) and river terrace deposits (for example, the Kempton Park, Taplow and Shepperton Gravels). 


\section{Limitations in use of the traditional geological map for ground investigation and development planning}

The case for using geo-environmental information to underpin preliminary site appraisal and for developing regional strategies has been made elsewhere and is discussed by Bobrowsky, 2002; Ellison et al., 2002, Culshaw and Ellison, 2002; Ellison et al., 1998; McKirdy et al., 1998 and Thompson et al., 1998. In the UK, studies commissioned by the then Department of the Environment in the early 1980s, suggested that much of the information contained within the traditional geological map was not being incorporated into planning and development decisions. This led to the development of the applied geological map; the function of this new type of map was to supply interpreted earth science information to planners. More than 50 studies were undertaken (Smith and Ellison, 1999) to promote the use of these maps in identifying the principal geological factors which should be taken into account during the planning process.

The main limitation of these applied 2D geological maps was their inability to convey information clearly in 3D. Some depth information was included, such as: the thickness of the superficial deposits (e.g. Powell et al. 1992), depth to bedrock (e.g. Lake et al., 1992), thickness of specific formations (Barclay et al. 1990) and contour lines of the phreatic groundwater (e.g. Powell et al., 1992). A good example of this was the use of a stipple (a variation on the 'stripe' method of Pasak and Rybar, 1961) to indicate bedrock and engineering geological units below surface (Forster et al. 1995). The resultant maps contained stripes of colour for the underlying bedrock as well as those for the engineering geological unit. These maps had a very complex appearance, which formed a barrier to their uptake by non-geoscientists. Nevertheless, the main short-coming with these maps was their inability to portray superficial materials present between at the ground surface and the bedrock. This limitation restricted the use of these maps in areas where complex assemblages packages of superficial deposits existed, such as beneath many towns and cities, including London.

It has long been recognised that existing or legacy data are an important part of desk study (Anon, 1999) and form the basis of the preliminary risk assessment. Roberts (1964) eloquently showed that ground investigations that took little or no notice of existing knowledge lead to greater costs later on. More recently, the Institution of Civil Engineers 
commissioned a report on the importance of site investigations (2004), which again emphasised the importance of using existing information.

BGS holds large quantities of geological information, much of which is in digital form. Data are in the form of geological maps, tunnel maps, borehole logs, site investigation reports, water abstraction boreholes and geochemical samples, but how should this information be presented?

Currently the desk study is used to provide a 3D conceptual model of the subsurface, which ideally should be produced before the start of the site investigation phase of a project. However, this is usually created after or during ground investigation work rather than before (Culshaw, 2005). The notion that a conceptual model should be used to design the site investigation is discussed in detail by Fookes (1997) and Fookes et al. (2000). Here they argued that knowledge of the geology and geomorphology of a site could be used to indicate the ground conditions most likely to be encountered.

Current advances in the use of Geographical Information Systems (GIS) and 3D modelling software have meant that there is now a far greater opportunity to develop geo-environmental information systems for urban development that can take greater account of the third dimension. In the TGDZ this has lead to the development of the a 3D attributed geological model. This has moved us away from the conceptual ground models of Fookes (1997) to bring us a step closer to real ground models of Culshaw, (2005). This paper describes the steps taken to produce digital 3D geological models of the shallow subsurface attributed with property information, as part of a desk study to aid planning and site investigation design.

The key developments necessary for this idea to be taken up widely lie in improvements in 3D modelling capabilities, which, in turn, depend on the availability of digital data and on improvements in 3D modelling software (Turner, 2006). Critically, it is the ability to build and visualise 3D models on a standard desktop PC without the need for expensive and operationally complex computer software which will encourage the regular use of 3D models.

In recent years, data has become increasingly available in digital format (Bowie 2005, Jackson 2004). This has necessitated changes in data management practice (Turner 2003, Culshaw 2005), such as the requirement for data to be spatially registered in nationally recognised coordinate and elevation systems and the move towards corporate databases which 
have nationally agreed data standards and validation procedures (Baker and Giles 2000). Developments in 3D modelling technology mean that 3D models can be produced quickly and updated easily, a significant step forward from previous 3D modelling systems (Strange et al. 1998). Geological 3D models can also be supplied to planners and developers in either GIS compatible formats or within a 3D viewer, both of which can be viewed on a standard desktop PC (Royse et al. 2006a). Thus, such advances in 3D modelling technologies have now made the $3 \mathrm{D}$ geological model a practical option for site investigation work.

Once the 3D geological framework has been constructed, the physical attributes of the modelled geological units (3D polygons) can be described. This attributed geological model is now able to encapsulate, at least in part, some of the natural variability of real geological systems. Rosenbaum (2003) considered this to be one of the four major impediments to 3D modelling not being widely used within the geotechnical industry. The method of attribution described within this paper is not able to take into account the heterogeneity within a modelled geological unit (Group, Formation, Member or Bed) but rather it provides the user with bulk attributes for a given unit. This has been done for two reasons: firstly, the process of discretisation (whereby each modelled unit is split into a series of 'volume' elements, often cubes) results in very large data files being generated (Turner 2006), which are difficult to handle, making data manipulation on a standard desktop PC unworkable. Secondly, to model property variation within a geological unit without an unfeasibly high level of uncertainty, it is essential that geoscientific data is of a high density and quality throughout the modelled area. In the TGDZ, although a large amount of geoscientific data exists, the quality of the data is highly variable making modelling of 'within-unit heterogeneity' impracticable.

Nevertheless, heterogeneity within a modelled unit can be visualised by using a variety of graphical techniques which will be discussed later in this paper.

A modelling system has been adopted at BGS which produces not only detailed 3D models (Howland, 2000, Strange et al. 1998), but models attributed with physical, chemical or hydrogeological parameters (fig 2). Once the attributed 3D model is completed a large number of customised geoscientific outputs can be generated with little computation. This paper will describe this system and outline some of the customised outputs which have been developed for the TGDZ.

\section{Fig. 2}




\section{D Geological modelling in the Thames Gateway}

The geological model of the TGDZ was constructed using proprietary software GSI3D (Geological Surveying and Investigations in 3 Dimensions), produced by Insight (Hinze et al. 1999; Sobisch 2000; Kessler et al. 2004) and described by Culshaw (2005). The main reason why many professionals do not use 3D modelling routinely is because many modelling packages are too complex (Hack et al. 2006). GSI3D gets around this problem by using traditional techniques of cross-sections and fence diagrams, together with a generalised vertical section (Fig 3, Kessler and Mathers, 2004).

\section{Fig. 3}

The Thames Gateway model has been built from over 4000 boreholes and over 200 northsouth and east-west trending cross-sections. The model was constructed using a generalised vertical section of the lithostratigraphy, which, when combined with the generated crosssections, created a fence diagram of the geology. The superficial and bedrock layers were then further constrained by the recent 1:10 000-scale digital geological mapping and the digital terrain model (DTM).

\section{Data sources}

The integrity of the 3D attributed geological model depends on having an array of accurately logged boreholes, good down-hole geophysics and access to other site investigation data at a sufficient density to allow geological units (including groups, formations, members or beds dependent on the level of detail required) to be modelled and their physical properties to be characterised with confidence.

\section{Geotechnical data}

Site investigation reports provided the primary source of geotechnical data in this study. The data was entered into the National Geotechnical Properties Database (NGPD), which follows the Association of Geotechnical and Geoenvironmental Specialists (AGS) digital format tables. The data is in an Access $(\subset$ database, which is backed up in Oracle $($ ). The data is 
exported and usually manipulated in Excel@ $\mathbb{C}$. This database contains geotechnical data from over 3200 boreholes and trial pits from the TGDZ.

\section{Hydrogeological data}

Hydrogeological data incorporated into the model consisted of well and water borehole logs, borehole geophysical data and groundwater level surfaces and contour plots. Existing groundwater level surfaces or contour data used in this study were obtained from: January 1990 (Environment Agency, 1990), January 2004 (Environment Agency, 2004), 1965 (Ellison, 2004), “Pre-development” (Water Resources Board, 1972), and modelled groundwater levels for February 1995 and October 1997 (Jackson and Spink, 2004). The most useful dataset was the modelled groundwater levels of Jackson and Spink (2004) as these proved to be the most reliable and provided full coverage of the Thames Gateway model between Thurrock and Dartmouth, (a focus for hydrogeological attribution). Borehole data were collated from the BGS WellMaster database, the Swanscombe groundwater modelling project (Jackson et al. 2004), and from the Environment Agency.

Groundwater level data obtained from borehole logs proved to be limited within the area of interest and only 58 post-1980 groundwater levels could be identified in, or near to, the Thurrock-Dartford hydrogeological study area. Point data was used principally to highlight potential anomalies in the modelled groundwater level data.

\section{Attribution of the Thames Gateway 3D Geological Model}

To gain full value from the 3D geological model in the urban environment, attribution of the model with engineering geological and hydrological data is necessary. The 3D model is attributed by assigning property values for each geological unit modelled (be that Group, Formation, Member or Bed). Bulk attribution provides a way of visualising the property characteristics of each geological unit modelled and their spatial relationships. The TGDZ model has been attributed with several datasets including lithostratigraphy, engineering geological classification, ground water productivity and, maximum and minimum permeability. 


\section{Engineering geology}

The 3D geological model provides a framework on which spatial presentation and interpretation of geotechnical data can be undertaken. From this, an engineering geological classification scheme can be formulated and then engineering geological ground conditions can be visualised in 3D space. The engineering geology attribution is based on the classification scheme developed in thematic mapping projects described above (Forster et al. 2004).

The geological units are primarily divided in terms of engineering 'rocks' and 'soils'. In the TGDZ, much of what is classified as bedrock by the geologist is classified as a soil by the engineer. The exception is the White Chalk Sub-Group, although the upper part is often weathered to a 'putty' chalk, which also, for engineering purposes, behaves as a 'soil'. These primary divisions are further subdivided into coarse-grained (sand and gravel), fine-grained (clay and silt), organic soils (peat) and mixed soils, (which contain discrete fine and coarse beds or mixtures of both). Most of the geological units classified as fine or coarse are, to some extent, mixed, for example the London Clay Formation, which is predominantly clay also contains beds of sand at some levels, and the Thanet Sand Formation, which predominantly consists of fine sand, may also contain beds of silt and clay. Secondary divisions further classify the modelled units on the basis of general strength or density. These subdivisions are based on log descriptions, undrained shear strength and standard penetration tests, plus any other appropriate parameters included in site investigation reports.

This description only provides an average value for each modelled formation. The majority of formations within the TGDZ display a significant amount of heterogeneity. To combat this, the 3D modeller can model the geological units at a higher resolution i.e. down to the member or bed level but this may not always be possible, in which case intra-formational variation can be displayed as either statistical plots or shown within borehole sticks. Strength or density data can easily be described within statistical plots or cross plots which can be attached via hot links to the attributed model. Figure 4 is an extended box and whisker plot showing the percentiles (Culshaw, 2005) of SPT N-values for the terrace gravel deposits. It shows that the majority of these deposits are medium dense to dense (that is SPT N-values of 10 to 30 and 30 to 50 ), with median values of about 30 .

\section{Fig. 4}


Figure 5 shows and Table 1 describes the 3D engineering geology attribution for the central part of the Thames Gateway.

\section{Table 1}

\section{Fig. 5}

\section{Hydrogeology}

Parameterising the 3D geological model enables the user to view and analyse the vertical and lateral variation in rock properties, rather than the variation in lithostratigraphy. For example, if the user wanted to identify high permeability units at depth, say for the assessment of aquifer storage and recovery potential, they can easily identify these units, their depth, thickness, and lateral extent, all of which can affect the prospects of a successful scheme.

For the Thames Gateway 3D model hydrogeological classification schemes for permeability indices (provides an indication of the range of permeability likely to be encountered for each geological unit) and permeability types were taken from the attributed 1:50 000-scale Digital Geological Map of Great Britain (DiGMapGB) table (Lewis et al. In press) and aquifer type was based on the Environment Agency's classification scheme for the Water Framework Directive (WFD). An example of a resultant model for part of the Thames Gateway model between Thurrock and Dartford is shown in figure 6. In this case the 3D model has been attributed to illustrate the Environment Agency’s WFD Aquifer Classification scheme. The 'exploded' view of the model allows the user to appreciate the relationship between the lithostratigraphical and hydrogeological units. By using the model in this way, a clearer understanding of the complexity and spatial variability of the lithological sequence within the Thames Gateway region can be gained. This provides a means for assessing the potential hydrological performance of any lithological sequence modelled. Furthermore, the model can be used to define accurately areas of recharge and discharge, which could be used to inform water resource management strategies at a regional and site specific level. The model can also be used to evaluate potential pollution pathways at the site scale; this is particularly useful when considering the potential pathways that new foundations may provide between surface and groundwater aquifers.

\section{Fig. 6}




\section{Applications of the Attributed Geological Model in the Thames Gateway Development Zone}

The resultant attributed geological model can then be used to predict not only the rock and soil types, but their vertical and lateral variation and also the variation in their engineering properties (such as rock strength, shrink-swell characteristics, compressibility etc), and hydrogeological properties (such as permeability, porosity etc). The model can also inform the user about general engineering geological and hydrogeological ground conditions, such as thickness of the unsaturated zone or the presence of perched water tables or the depth to good foundation conditions. The 3D geological model is now gaining the ability to encapsulate the natural variability of geological features (Turner 2006). Several examples of how the attributed TGDZ 3D model has been used to communicate geoscientifically complex ideas are presented.

\section{Displaying attributions at different depths}

Different surfaces other than the DTM can be used to 'slice' the model. For example, the piezometric surface can be used to create a map of the geology at the water surface. This is done by intersecting the surface with the geological model. By analysing such maps, much additional insight can be gained about the hydrogeological regime. It is then possible to understand visually where water levels are confined or unconfined.

It is also possible to slice the model at different depths below ground level. This has been done using the engineering geology classification in Figure 7 for surfaces at, $1 \mathrm{~m}, 5 \mathrm{~m}$ and 10 $\mathrm{m}$ below ground level. The resultant surfaces can be used to predict the presence or absence of problematic material, such as peat.

\section{Fig. 7}

\section{Presentation of borehole Information}

As described above, attribution of the model is confined currently to bulk properties of modelled units be that at the group or bed level. Variation of parameter values within a model unit cannot be shown by just using the model and have to be described as part of the attribute classification. Within this modelling system, it is possible to display variation by using 
'borehole sticks', which are correctly positioned within the model, in sections or within the 3D model (fig 8).

A wide range of data can be shown in this way, including: lithology, strength or density descriptions, weathering classification, water level data, geotechnical, geophysical and geochemical parameters. Each of these factors is classified and assigned a colour. A number of parameters may be shown together with the lithostratigraphy in adjacent 'borehole sticks,' such as lithology and geophysical logs. This may not suit all parameters as the classification in some cases, can reduce details required to make a valid interpretation. However, for a large proportion of geoscientific data, this provides a useful way of viewing intra-formational variability. A log showing temperature and conductivity variation with depth for borehole TQ47NE696 is shown in figure 9.

\section{Fig. 8}

\section{Fig. 9}

Another use of the 'borehole stick' method is in displaying groundwater level data obtained from borehole records. A minimum and maximum water level was obtained from borehole records and the data displayed as 'borehole sticks'. This method provides a clear indication of the position of the water table when plotted in conjunction with geological cross-sections or fence diagrams. The water level data can then be displayed together with the geological model.

\section{Geotechnical and engineering applications}

Engineers and geologists can use the model for different purposes: to assist in the recognition and identification of problematic ground conditions; as a tool to aid in the planning process; to help locate ground investigations and to ensure that the most economical and valuable information is obtained from ground surveys.

Exstension of construction onto sites on, or near, the River Thames floodplain will necessitate an understanding and consideration of the geological and physical properties of the alluvium and peat. In general, the alluvium and peat are of very low to low strength (Anon., 2004) and also, their strength does not increase significantly with depth. The low strength and, therefore, 
high (and potentially uneven) settlement provides poor foundation conditions, restricting the foundation type and loading that can be applied.

The engineering classification (Table 1) applied to the 3D attributed model reflects these properties and therefore the model can be used to assess the suitability of each geological unit within the modelled area for use as a founding material. In the case of the Thames flood plain, the best geological units on which to establish foundations are: the Taplow, Kempton Park and Shepperton Gravels formations, or the White Chalk Sub-group.

The 3D attributed model can also be used to provide information on the depth to founding material, its properties and the variability of these properties. The depth to the top of the gravel formations and Chalk beneath the alluvium can be exported from the 3D model and displayed as depth or thickness (isopac) contour plots in ArcGIS (Figures 10). It is then possible to combine the 3D surfaces with other spatially rectified data (be that geotechnical, geochemical, or geographical etc) which, when combined together, provides a way of assessing the suitability of sites for a variety of construction techniques.

The 3D attributed geological model can also be used to generate engineering geological crosssections along a given linear route, such as a railway track, road or flood defence barrier. Spatial attribution of geotechnical data and simple methods to recast sections in engineering geological terms are easily realised using these new techniques. A simple visual inspection of Figure 11 allows regions of potentially difficult ground conditions to be immediately identified. It is now not sufficient to identify fine-grained soils as locations for potentially problematic ground conditions, as was done in the past using a traditional geological map. Much more information is required about the geological structure, lithological variability, mineralogy, moisture content and geotechnical properties of the rocks and soils, much of which can be supplied by emerging 3D geospatial databases. These databases can be interrogated at key depths (as shown above) providing an indication of the wide variability of geological materials and conditions beneath the ground surface. Detailed geological sections along linear routes can be modelled and the locations of potential problematic rocks and soils, such as alluvium and peats, can be identified (Figure 11). Such attributed sections could become a key tool in strategic infrastructure (e.g. pipelines, roads and railways) maintenance and network expansion plans.

\section{Fig. 10}




\section{Fig. 11}

\section{Hydrogeological applications}

The Thames Gateway 3D attributed geological model can be used as a framework to help develop a conceptual model of the hydrogeological system essential in understanding water movement and pollution transport.

The starting point for any hydrogeological conceptual model is a description of the geology so it follows that, to improve the conceptual hydrogeological model, geological knowledge and understanding must be improved first. The advantage of a 3D model is that geological and hydrogeological information can be viewed simultaneously providing the hydrogeologist with the tools necessary to incorporate more detailed geological information into the groundwater model.

Groundwater level data can be difficult to use, partly because of its limited availability in digital format and partly due to the dynamic nature of groundwater levels. In the unconfined Chalk, groundwater levels may vary by tens of metres per year. In the London Basin, there is the additional problem that groundwater levels were depressed for decades due to abstraction, but since the 1960s have been recovering. Thus, one of the starting points was to examine the available groundwater information and decide on the most appropriate data to use. For the initial development of the model, the output from a groundwater flow model was used. This will be replaced in the longer term as new groundwater datasets become available digitally.

Once the groundwater surface has been calculated, it can be added into the model. In this way, the relationships between the groundwater level (potentiometric) surface, geological horizons and the land surface can be easily visualised. This further aids the development of the hydrogeological conceptual model, for example, by identifying higher permeability horizons, within which the groundwater surface is constrained. It may also serve as a check on the potentiometric surface, identifying areas where the contour data or interpolation is incorrect. Displaying the potentiometric surface together with the DTM allows potential areas of flooding to be delineated.

The simulated groundwater level surface for February 1995 is shown together with the DTM (Fig. 12). This clearly indicates the relationship of the groundwater surface with the land 
surface, for example, its relationship to the various marshes along the banks of the River Thames and the intersection of the water table with Eastern Quarry, a large chalk quarry to the south of the Thames. This model can also be used to delineate and visualise areas at risk from groundwater flooding, for example, where the potentiometric surface is close to the land surface.

\section{Fig. 12}

The natural development of karst features in the Chalk is known to be related to Chalk lithology and proximity to the potentiometric surface (Farrant, 2001). Using a 3D model containing detailed Chalk lithostratigraphy (Bristow et al. 1997) it is possible to highlight zones which would favour conduit development, such as the boundary between the Seaford and Lewes Nodular Chalk. Such areas can develop extensive natural cave systems, such as at Strood Waterworks (TQ729693) in the TGDZ, where a 60 m natural cavern was discovered during tunnelling works in 1879 (Bradshaw et al. 1991). Using the attributed geological 3D model in this way will improve understanding of the groundwater flow regime, resulting in improvements in the protection of existing groundwater abstractions and the development of new abstraction boreholes.

For the area around Thurrock in the north and Swanscombe in the south, the geological map at the potentiometric surface indicates that the Chalk aquifer is confined in the north but unconfined in the south. By creating maps for a high and low water level, it is possible to identify where water levels have the greatest range of fluctuation, which may be a result of pumping, recharge or the properties of the aquifer itself. This type of analysis identifies the anomalous areas and provides input into the conceptual hydrogeological model.

The 3D model could also be used to assess the risk of a new development contaminating the local groundwater supplies. Contamination studies concentrate on the linkages between source and receptor. The 3D model can be used to assess these potential links. An example of this is the Lower Lea Valley. Here, thick sequences of superficial deposits comprising River Terrace Gravels and Alluvium are underlain by Palaeogene deposits of the London Clay Formation with the Lambeth Group below. A detailed description is given by Ellison et al. (2004). Where the London Clay is absent and the superficial deposits rest on the Lambeth Group (which consists of interbedded layers of clay and sand) for example, near Stratford Marsh, there are significant implications for the development of pathways from the surface to 
the Chalk aquifer. As the Lambeth Group is extremely variable, it is likely that, at some locations, the clay layers may be thin or absent; consequently, the Chalk aquifer will be partially or wholly unconfined, that is, unprotected at these localities. A similar situation occurs in the Kempton Park gravels where irregularities in the rockhead surface (scour hollows) are known to exist (Berry 1979). The scour hollows can be as much as $15 \mathrm{~m}$ in depth; in these instances, the scouring will have removed the clay layers from within the Lambeth Group and, as a result, a direct pathway is established between surface water and the Chalk aquifer. By using the 3D geological model it is possible to locate sites where these situations are likely to occur and hence, at an early stage, identify these potentially problematical ground conditions.

\section{Confidence attribution}

Confidence or uncertainty modelling provides a way of visualising the differences between a digital representation and the real phenomenon. Shallow subsurface modelling, in particular, requires a high level of feature resolution; more precise property matching and the ability to differentiate conditions in a noisy environment (Rosenbaum, 2003) make the differences between the digital representation (the 3D model) and reality more acute. If the 3D attributed geological model is to be used to plan ground investigations, then effort is required to provide the user with the means to assess the accuracy of the model. The key issue here is in the certainty that can be placed on the spatial position of a given modelled horizon. As these models can be used by a far wider group of users than was traditionally the case for the 2D paper map, it is essential that confidence is expressed clearly (Culshaw, 2005). According to Evans (2003), there are two areas of uncertainty: firstly those associated with the data and measurements themselves and secondly, those inherent to the modelling process.

In trying to understand confidence and then to find a way to semi-quantify and visualise it, where the lack of certainty is located within our model must be identified. The way this is done is to construct a cause and effect diagram or Fish Diagram (Kindlarski 1984). Once done, it is then necessary to quantify certainty in such a way that users can easily understand it. In the case of the 3D geological models produced in the TGDZ, it was found that there are three main issues that will adversely affect the confidence of a model: data quality, data quantity and geological complexity. This is supported by work undertaken by Cave and Wood (2003) where they looked at the uncertainty of geological modelled surfaces and carried out a 
bootstrap re-sampling exercise on the data (Chernick 1999). They found that the mathematically calculated error was close to the true error in the data. They also showed that areas of greatest uncertainty were related to areas which lacked data points or where the shape of the surface is changing rapidly (in other words where the geology is unpredictable).

Clarke (2004) discussed a process for assigning confidence to geological interpretations and the assessment of geological complexity. He produced a generic confidence evaluation scheme for the geological interpretation and assessment of complexity. The geology of the TGDZ is a relatively simple layer cake system, which means that sources of error caused by geological complexity in this case generally can be limited to certain lithostratigraphical interfaces such as the base of the gravels beneath the alluvium and above the bedrock.

In the assessment, each piece of data used to model each surface was given a confidence value as to its quality on a scale of 1 to 10 (10 being excellent and 1 being very poor). This included borehole data, geological map data and cross-sections which were drawn up during the course of the modelling process. The geological map data and cross-section lines at this point were converted into point data (at spacing appropriate to the project) so that accurate quality values could be assigned. For example, geological line work for bedrock that is covered in superficial deposits is generally less accurate than bedrock geology lines where little or no superficial cover exists.

The data were then collected together for each modelled surface. It was necessary to add null values across the modelled area where there were no data. To have a regular spread of null points at an appropriate cell size, a grid was generated and null values added where no modelled data were present. The data were then interpolated using an inverse distance weighted technique (Shepard 1968) and cut to outcrop.

The resulting grids display a confidence range for each boundary surface within the model (Fig. 13). These grids can be displayed within a GIS or a 3D modelling package alongside the modelled surfaces. The grids graphically portray, to a large extent, what a trained geologist identifies as a matter of course. This lends further credence to the technique used and provides a simple but structured method for displaying, to both clients and the public, the confidence range for each surface.

\section{Fig. 13}


The method demonstrated here is not entirely objective and does not rely totally on mathematical calculations. However, It does, rely heavily on the subjective input from the interpreter, particularly in the assessment of quality. Therefore it is essential that the assessment of data quality is done concurrently with data collection. Retrospective confidence assessments have been found to be both time-consuming and less reliable (Clarke 2004).

The use of attributed 3D models in decision-making results in models being used to make predications as to the likely condition of the shallow subsurface at a particular site. Any such prediction will have an element of uncertainty and risk attached to it (Turner 2006). The generation of the 3D model in itself requires an element of prediction between known data points. Consequently, uncertainty modelling is an integral part of the 3D attributed modelling process. The simple method suggested here allows for a record of the uncertainty within the modelling procedure to be documented and provides a way to present the results visually to potential users.

\section{Summary and Conclusions}

The main failing of the traditional geological map, whether in its paper or digital form, is that it requires the user to have an understanding of geoscientific principles. Increasingly, there is a need for people from outside the traditional geoscientific user community to have access to geological information (Culshaw 2003). This has necessitated a change in the way that geoscientific data are displayed and interpreted, resulting in the construction of the 3D attributed geological model. The benefit of the attributed geological model over the more traditional geological map is that it allows the user to visualise the complex relationships between geological formations and units, to observe how, for example, the piezometric surface and geology interact and to appreciate the link between the physical characteristics of each formation or unit.

The value in having large quantities of geoscientific information, as is the case in the TGDZ, is not in the possession of it, but in the interpretation and presentation of that data to those that need it most. One way of achieving this is by adopting a modelling system such as described here, whereby not only are detailed and regional 3D models produced (Howland, 2000; Strange et al. 1998) but models attributed with physical, chemical or hydrogeological parameters. Once the attributed model has been created, it is possible to generate a large number of customised geoscientific outputs with little extra computation. 
Rosenbaum (2003) suggested that there were four reasons why 3D geological models of the shallow subsurface were not used routinely for site investigation design. These can be summarised below as:

- The lack of 3D and 4D mathematical, cognitive and statistical spatial tools

- The lack of modelling tools specifically designed for shallow subsurface modelling which are not too expensive and do not require specialist personnel to operate them

- The inability of models to depict accurately the natural variability of geological systems or to represent uncertainty

- The worry that the investment in time and effort to produce 3D models would not result in significant improvements in knowledge or better science

Since Rosenbaum listed his concerns the development of the 3D attributed geological model of the shallow subsurface has moved a significant step forward towards reaching his goals. The key development necessary for models of the shallow subsurface to be used routinely in planning and site investigation design lies in the ability to build and visualise 3D models on a standard desktop PC without the need for expensive and operationally complex computer software. Not only can the modelling system used here (GSI3D) be used on a standard desktop PC but also the 3D model is built by using traditional geological techniques which are familiar to geologists, engineering geologists and hydrogeologists, negating the need for specialist operators.

The attributed 3D model provides a platform whereby the integration and visualisation of data from many different sub-disciplines can be achieved. This allows the model to portray some of the natural heterogeneity of real geological systems. The level of geological detail contained within the model will always be dependent on the amount and quality of the digital data available, as is the case in the examples given in this paper. Nonetheless, it has been have shown that a considerable amount can be accomplished by bulk attribution of a geological model, whereby an understanding can be gained about general geotechnical, geological and hydrogeological ground conditions, such as thickness of the unsaturated zone or the presence of perched water tables or the depth to good foundations. Also, it has been shown that by simply incorporating a wide variety of hydrogeological information into the 3D geological model, it is possible to improve understanding and knowledge of the groundwater system and 
develop a better conceptual hydrogeological model for part of the TGDZ. Further work is needed to model the full heterogeneity displayed within real geological systems; nevertheless, it is possible to portray intra-formational variability by using statistical plots or 'boreholesticks' spatially registered within the model.

All users of digital geoscience data, in particular 3D models, must understand the limitations of the data on which they base their assessments. This is becoming more critical as improvements in 3D modelling techniques are allowing geoscientists to introduce a far greater level of realism into their models. Therefore it is essential, , that users of these data can differentiate between observed and conjectural information. This is often referred to as the inherent uncertainty of a digital 3D model and the geoscientific datasets on which it is based. There are still difficulties in the presentation of uncertainty calculations, making the resulting graphical representations difficult to interpret and use (Clarke 2004). However, a simple method for determining the uncertainty within a model has been outlined, which can be used alongside the attributed geological model, to provide a clearer picture as to the validity of the model. Users, ultimately, will need to be able to assess the risk associated with using these models, so that sound judgments can be made.

In summary, the 3D attributed geological models will transform the way geological maps are made and produced and change the way groundwater modelling and ground investigations are carried out. For example, site investigations will become more targeted, concentrating on areas where the engineering or hydrogeological behaviour is known to be complex or where there is little data. As a result, the future proposed by Culshaw (2005), where ground investigations will start by testing the validity of a 'real' geological model, is rapidly becoming a reality.

\section{Acknowledgements}

This paper is published with the permission of the Executive Director of the British Geological Survey (NERC) 


\section{References}

Anon. 1995. The Thames Gateway Planning Framework. RPG9A. HMSO 77p

Anon. 1999. Code of practice for site investigation, BS5930. British Standard Institution, London, 204p

Anon. 2004. Geotechnical investigation and testing - Identification and classification of soil - Part 2: Principles for a classification (CEN ISO 14688-2:2004). British Standard Institution, London.

Baker G R, and Giles J. 2000. BGS Geoscience integrated database system : a repository for corporate data. In: Earthwise, vol 16. pp 12-13

Barclay W J, Ellison R A, and Northmore K J. 1990. A geological basis for land-use planning: Garforth-CastlefordPontefract : 1:10 000 sheets SE42NW,NE, SW, SE, SE43SW and SE52SW, parts of 1:50 000 geological sheets 70 ( Leeds) and 78 (Wakefield): British Geological Survey, Technical Report WA/90/3. 111p

Berry, F.G., 1979. Late Quaternary scour hollows and related features in central London. Quarterly Journal of Engineering geology, 12: 9-29.

Bobrowsky, P T. 2002. Geoenvironmental mapping: methods, theory and practice. Lisse: AA Balkema.

Bowie R. 2005. Creating a digital landslide. Geoscientist 15 (3): 4-7

Bradshaw J, Caiger N, Halpin M, Le Gear R, Pearce A, Pearman H, Reeve T and Sowan P. 1991. Kent and East Sussex Underground. Meresborough Books. 128p

Bristow R, Mortimore RN and Wood C J. 1997. Lithostratigraphy for mapping the Chalk of southern England. Proceedings of the Geologists Association 109: 293-315

Cave, M R, \& Wood, B. 2003. Approaches to the Measurement of uncertainty in geoscience data modelling:. British Geological Survey Internal Report, IR/02/068. pp 38

Chernick, M R. 1999. Bootstrap Methods, A practitioner's guide. Wiley Series in Probability and Statistics.

Communities and Local Government. 2006a. Planning Policy Statement 25: Development and Flood Risk. Full regulatory Impact Assessment. Communities and Local Government Publications. 26 p.

Communities and local Government. 2006b. Planning Policy Statement 9: Biodiversity and geological conservation. Final Regulatory Impact Assessment. DCLG publications. 10 p

Clarke S M. 2004. Confidence in geological interpretation. A methodology for evaluating uncertainty in common two and three-dimensional representations of subsurface geology. British Geological Survey Internal Report, IR/04/164. pp 29

Culshaw, M G and Ellison, R A. 2002. Geological maps: their importance in a user-driven digital age. In Van Roony, J L, \& Jermy, C A. (Editors), Proceedings of the $9^{\text {th }}$ International Association for Engineering Geology and the Environment Congress, Durban, 16-20 September 2002. Keynote Lectures and Extended Abstracts Volume, 25-51. Pretoria: South African Institute of Engineering and Environmental Geologists [ISBN 0-620-28560-5]. Also pages 67-92 on CD Rom [ISBN 0-62028559-1].

Culshaw M G. 2003. Bridging the gap between geoscience providers and the user community. In: Rosenbaum MS, Turner AK (eds) New paradigms in subsurface prediction, Lecture notes in earth sciences 99. Springer-Verlag, Berlin, pp 7-26 
Culshaw M G. 2005. From concept towards reality: developing the attributed 3D model of the shallow subsurface. Quarterly Journal of Engineering Geolology and Hydrogeology, 38: 231-284.

Ellison, R A, McMillan, A A, and Lott, G K. 2002. Ground characterization of the urban environment: a guide to best practice. British Geological Survey Internal Report, IR/02/044.

Ellison, R A., Arrick, A, Strange, P J and Hennessey, C. 1998. Earth science information in support of major development initiatives. British Geological Survey Technical Report, WA/97/84.

Ellison R. 2004. Geology of London - special memoir for 1:50,000 geological sheets 256 (North London), 257 (Romford), 270 South London) and 271 (Dartford) (England and Wales), $114 \mathrm{p}$

Environment Agency. 1990. Rising groundwater levels in the Chalk-basal sands aquifer of the Central London basin - 1990. Unpublished report.

Environment Agency. 2004. Rising groundwater levels in the Chalk-basal sands aquifer of the Central London basin - May 2004. Unpublished report.

Evans R. 2003. Current themes, issues and challenges concerning the prediction of subsurface conditions. In: Rosenbaum MS, Turner AK (eds) New paradigms in subsurface prediction: characterisation of the shallow subsurface: implications for urban infrastructure and environmental assessment. Springer-Verlag, Düsseldorf, pp 359-378

Farrant A R. 2001. Karst development in southern English Chalk. In: Beck BF and Herring JG (eds) Geotechnical and Environmental applications of karst geology and hydrology. Swets and Zeitlinger pp77-82

Fookes P G. 1997. Geology for engineers: the geological model, prediction and performance. Q J Eng Geol 30: 293-424

Fookes P G, Baynes F G, Hutchinson J N. 2000. Total geological history: a model approach to the anticipation, observation and understanding of site conditions. Proceedings of the International Conference on Geotechnical and Geological Engineering, Melbourne, Australia, 1. Technomic publishing Co, Lancaster, Pennsylvania, USA: 370-460.

Forster A, Arrick M, Culshaw M G, Johnston M eds. 1995. A geological background for planning and development in Wigan. Technical Report WN/95/3. British Geological Survey. pp 151.

Forster, A, Lawrence, D J D, Highley, D E, Cheney, C S and Arrick A. 2004. Applied geological mapping for planning and development: an example from Wigan UK. Quarterly Journal of Engineering Geology and Hydrogeology, 37, 301-315.

Hack R, Orlic B, Ozmutlu S, Rengers N. 2006. Three and more dimensional modelling in geo-engineering. Bull Eng Geol Env 65:143-153

Hinze C, Sobisch H-G, Voss H-H (1999) Spatial modelling in geology and its practical use. Mathematische Geologie 4: 5160

Howland A.F. 2000. The history of the development of procedure for the rapid assessment of environmental conditions to aid the urban regeneration process at London Docklands. Engineering geology, 60, 117-125

Jackson C R, Spink A E F (2004) User’s manual for the groundwater flow model ZOOMQ3D. British Geological Survey Internal Report, IR/04/140. pp 94

Jackson C R, Hughes AG, Bloomfield J P and Rutter H K (2004) Numerical modelling of groundwater flow in the Darent catchment and Swanscombe area Chalk aquifer. British Geological Survey Commissioned Report, CR/03/183C. pp 140. 
Jackson I. 2004. Britain beneath our feet. In: British Geological Survey Occasional Publication No. 4, pp 114

Kessler H. and Mathers S. 2004. Maps to Models. Geoscientist, 14 (10) : 4-6

Kesslar, H., Mathers, S J \& Sobisch, H.-G. 2004. GSI3D: The software and methology to build near surface 3-D geological models. BGS Internal Report, IR/04/029.

Kindlarski E. 1984. Ishikawa diagrams for problem -solving. Quality Progress 17 (12): 26-30

Lake R D, Northmore K J, Dean MT and Tragheim D G. 1992. Leeds : a geological background for planning and development : 1:10000 sheets SE23NW, NE, SE and SE33NW, NE, SW, SE : parts of 1:50000 geological sheets 69 (Bradford), 70 (Leeds), 77 (Huddersfield) and 78 (Wakefield). British Geological Survey, Onshore Geology Series, Technical Report WA/92/001. pp 83

Lelliott M.R., Bridge D.M., Kesslar H., Price S.J. and Seymour K.J., 2006. The application of 3D geological modelling to aquifer recharge assessments in an urban environment. Quarterly Journal of Engineering Geology and Hydrogeology, 39: 293-302.

Lewis M, Cheney C and Ó Dochartaigh. (In press). The National Assessment of permeability indices. British Geological Survey Report.

McKirdy, A. P., Thompson, A. \& Poole, J. 1998. Dissemination of information on the earth sciences to planners and other decision-makers. In Bennett, M R, and Doyle, P. (eds), Issues in environmental geology: a British perspective. (Oxford: The Geological Society of London.)

ODPM. 2004. Planning Policy Statement 23: Planning and Pollution control. pp20

Pasak J and Ryber J. 1961. Die Darstellung ingeneieurgeologischerVerhaltnisse in der Karte 1:25 000. Zeitschrift für Angewandte Geologie 7 (3): 36-139.

Powell J H, Glover BW and Waters C N. 1992 A geological background for planning and development in the 'Black Country': British Geological Survey, Onshore Geology Series, Technical Report WA/92/33. pp 79

Roberts GD. 1964. Investigation versus exploration. Bull Assoc Eng Geol 1(2): 37-53.

Rosenbaum M S. 2003. Characterisation of the shallow subsurface: implications for urban infrastructure and environmental assessment. In: Rosenbaum MS, Turner AK (eds) New paradigms in subsurface prediction, Lecture notes in earth sciences 99. Springer-Verlag, Berlin, pp 3-6

Royse K R, Entwisle D, Price S, Terrington R. 2006a. Geoscience Solutions for the Thames Gateway. IAEG2006 Engineering geology for tomorrow’s cities. 1- 109: pp 9

Royse K R, Entwisle D, Price S, Terrington R, Venus J. 2006b. Gateway to Olympic success. Geoscientist 16(5): 4-10 Shepard, D. 1968. A two-dimensional interpolation function for irregularly-spaced data, Proc. 23rd National Conference ACM, ACM, 517-524.

Smith A and Ellison RA. 1999. Applied geological maps for planning and development: a review of examples from England and Wales 1983 to 1996. Q J Eng Geol 32: S1-S44

Sobisch H-G. 2000. Ein difitles raeumliches Modell des Quartaers der GK25 Blatt 3508 Nordhorn auf der Basis vernetzer Profilschnitte. Shaker Verlag, Aachen. 
Strange P.J, Booth S.J and Ellison R.A. 1998. Development of 'rockhead' computer -generated geological models to assist geohazards prediction in London. In Maund J.G. and Eddleston M. (eds) Geohazards in engineering geology. Geological Society Engineering geology special publication 15, 409-414

Thompson A, Hine PD, Greif JR and Poole J S. 1998. Environmental geology in Land Use and Planning: Advice for Planners and developers. Report to the Department of the Environment.

Turner A K. 2003. Putting the user first: implications for subsurface characterisation. In: Rosenbaum MS, Turner AK (eds) New paradigms in subsurface prediction, Lecture notes in earth sciences 99. Springer - Verlag, Berlin, pp 61-83

Turner A K. 2006. Challenges and trends for geological modelling and visualisation. Bulletin of Engineering Geology and the Environment 65:109 - 127

Water Resources Board. 1972. The hydrogeology of the London Basin. Unpublished report.

\section{Figure Legends}

Fig. 1. Geological Map of London and the surrounding area

Fig. 2. Flow diagram showing the process of building and applications of the 3D attributed geological model Fig.3. 3D geological model building work flow in GIS3D (after Kessler and Mathers, 2004)

Fig. 4. Box and Whisker plot of standard penetration test results for the terrace gravels in part of the Thames Gateway area. Where BHT = Boyne Hill Gravel Formation; LHT= Lynch Hill Gravel Formation, TPGR = Taplow Gravel Formation and RTDU = Kempton Park and Shepperton Gravel formations

Fig. 5. 3D block model of the engineering geological classification of the area between Dartford and Thurrock (see Table 1 for key).

Fig. 6. Exploded volume model illustrating the EA's WFD aquifer classification scheme

Fig. 7. Engineering characteristics at ground surface, and $1 \mathrm{~m}, 5 \mathrm{~m}$ and $10 \mathrm{~m}$ below ground surface. See Table 5 for key.

Fig. 8. Cross-section showing the variation of SPT values within the Thames Gravels and Chalk within grid square TQ57NW.

Fig. 9. Temperature and conductivity log for borehole TQ57SW29 (GR 551800,0174800).

Fig. 10. 3D geological model of the Lower Lea Valley, Stratford, London with automatically generated geological, and engineering geological cross-sections through the middle of the Lower Lea Valley

Fig. 11. Contour map of the thickness of the alluvium between Bexley and Tilbury displayed in ArcGIS generated from the 3D geological Model.

Fig. 12. Intersection of simulated groundwater table for February 1995 (blue) with DTM within the West Thurrock area. 
Fig. 13. Grids displaying confidence data in the Thames Gateway region between Woolwich and Gravesend for a) London Clay Formation, b) Thanet Sand Formation and c) the Chalk Group. Colour variation from blue to red indicating a change from low to high confidence.

\section{Table Titles}

Table 1. Engineering geological character of the surface geology in the Thames Gateway area. 
Online pre- publication :

http://www.springerlink.com/content/4675711620717848/

Bulletin of Engineering Geology and the Environment, 68 (1). 1-16

\title{
Property attribution of 3D geological models in the Thames Gateway, London: new ways of visualising geoscientific information
}

\author{
K.R. ROYSE () ) \\ H.K. RUTTER \\ D.C. ENTWISLE
}

British Geological Survey, Kingsley Dunham Centre, Keyworth, Nottingham, UK

Email: krro@bgs.ac.uk

Tel: +44-115-9363456

FAX: +44-115-9363593

Abstract

Rapid developments in information technology and the increasing collection and digitisation of geological data by the British Geological Survey now allow geoscientists to produce meaningful 3D spatial models of the shallow subsurface in many urban areas. Using this new technology, it is possible to model and predict not only the type of rocks in the shallow subsurface, but also their engineering properties (rock strength, shrink-swell characteristics and compressibility) and hydrogeological properties (permeability, porosity, thickness of the unsaturated zone or the likelihood of perched water tables) by attribution of the 3D model with geological property data. This paper describes the hydrogeological, engineering and confidence (uncertainty) attribution of high resolution models of the Thames Gateway Development Zone (TGDZ) east of London UK and proposes a future in which site investigation sets out to test a pre-existing spatial model based on real data rather than a conceptual model.

Keywords 3D modelling decision making Site Investigation attribution 


\section{Introduction}

The importance of good quality geo-environmental information is becoming increasingly important as legislative changes [e.g. in the UK, Planning Policy statement (PPS) 9, 23 and 25 (Communities and Local Government 2006 a \& b, and ODPM 2004) and Part IIA of the Environment Protection Act, 1990] have forced developers, to consider the implications and impact of large-scale development initiatives on the environment. To comply with the principles of sustainable development, developers are required to demonstrate that proposals are based on the best possible scientific information and analysis of risk. Therefore, increasingly, organisations involved in planning and development are now requiring access to geoscientific information in the past. Many of these organisations have not made much use of geoscientific information and find the traditional geological map difficult to interpret.

Advances in three dimensional modelling technology are providing the geoscientist with innovative ways to present geoscientific information to planners, engineers and developers. It is now possible to view and manipulate 3D models on a standard desktop computer and, more importantly, the model can be updated quickly and easily when new data become available. These are major steps forward from previous 3D urban modelling systems (Strange et al. 1998), which required a significant amount of specialist computer knowledge and access to large computing capabilities. Data outputs also tended to be static, as updating was difficult and time-consuming.

This paper will show how it is possible to attribute the 3D geological model with a variety of information, including geotechnical, hydrogeological and confidence data. The resultant model can be used to predict the type of rocks present within a particular site, as well as the variation in their engineering properties (strength, shrink-swell characteristics and compressibility) and hydrogeological properties (permeability and porosity).

The research on which this paper is based focuses on London and the Thames Gateway Development Zone (TGDZ) but builds on earlier work in Manchester and Salford (Culshaw 2005, Lelliott et al. 2006). The TGDZ was chosen because a large proportion of planned development projects will necessitate construction on ground that contains compressible soils, high groundwater levels and potentially contaminated brownfield sites, for which knowledge of the geology is crucial if sound decisions are to be made. 


\section{Geological setting}

The TGDZ is contained within the London Basin (Fig. 1). Geologically, the London Basin is a broad, gentle synclinal fold, whose axis can be traced from Marlborough through to Westminster. The London Basin formed in the Oligocene to mid- Miocene times during the main Alpine compressional event. Formations in this region range from Cretaceous (144 to 65 Ma) to Quaternary (2 Ma to present day) in age. The Cretaceous Chalk is typically a fine grained white limestone (Bristow et al.1997 provided a detailed description of the Chalk lithostratigraphy). It has a total thickness of between 175 and $200 \mathrm{~m}$ and generally thins from the West to the East.

\section{Fig. 1}

Overlying the Chalk is the oldest Palaeogene deposit, the Thanet Sand Formation. This Formation consists of a coarsening upwards sequence of fine-grained, grey sand. The formation reaches a maximum thickness of around $30 \mathrm{~m}$ in the area. A basal conglomerate (the Bullhead Beds) defines the base of the Thanet Sand, which consists of rounded black flint pebbles. Above the Thanet Sand Formation lies the Lambeth Group. This Group consists of three Formations: the Upnor, the Woolwich and the Reading Formations. The Lambeth Group is between 20 and $30 \mathrm{~m}$ thick in the area and lithologically is highly variable, consisting of differing proportions of sands, silts, clays and gravels.

Overlying this are the Eocene sediments of the Thames Group which consist of the Harwich and London Clay Formations. The Harwich Formation (formerly known as the Blackheath, or Oldhaven Beds) consists predominantly of sand and pebble beds up to $4 \mathrm{~m}$ thick. Above this is approximately 90 to $130 \mathrm{~m}$ of London Clay. The London Clay Formation consists of grey to blue grey, bioturbated, silty clay. Quaternary deposits are encountered right across the TGDZ. These include evidence of an ancient river system and the development of the present day River Thames valley. Deposits include alluvium, peat, brickearth (mostly wind blown sand) and river terrace deposits (for example, the Kempton Park, Taplow and Shepperton Gravels). 


\section{Limitations in use of the traditional geological map for ground investigation and development planning}

The case for using geo-environmental information to underpin preliminary site appraisal and for developing regional strategies has been made elsewhere and is discussed by Bobrowsky, 2002; Ellison et al., 2002, Culshaw and Ellison, 2002; Ellison et al., 1998; McKirdy et al., 1998 and Thompson et al., 1998. In the UK, studies commissioned by the then Department of the Environment in the early 1980s, suggested that much of the information contained within the traditional geological map was not being incorporated into planning and development decisions. This led to the development of the applied geological map; the function of this new type of map was to supply interpreted earth science information to planners. More than 50 studies were undertaken (Smith and Ellison, 1999) to promote the use of these maps in identifying the principal geological factors which should be taken into account during the planning process.

The main limitation of these applied 2D geological maps was their inability to convey information clearly in 3D. Some depth information was included, such as: the thickness of the superficial deposits (e.g. Powell et al. 1992), depth to bedrock (e.g. Lake et al., 1992), thickness of specific formations (Barclay et al. 1990) and contour lines of the phreatic groundwater (e.g. Powell et al., 1992). A good example of this was the use of a stipple (a variation on the 'stripe' method of Pasak and Rybar, 1961) to indicate bedrock and engineering geological units below surface (Forster et al. 1995). The resultant maps contained stripes of colour for the underlying bedrock as well as those for the engineering geological unit. These maps had a very complex appearance, which formed a barrier to their uptake by non-geoscientists. Nevertheless, the main short-coming with these maps was their inability to portray superficial materials present between at the ground surface and the bedrock. This limitation restricted the use of these maps in areas where complex assemblages packages of superficial deposits existed, such as beneath many towns and cities, including London.

It has long been recognised that existing or legacy data are an important part of desk study (Anon, 1999) and form the basis of the preliminary risk assessment. Roberts (1964) eloquently showed that ground investigations that took little or no notice of existing knowledge lead to greater costs later on. More recently, the Institution of Civil Engineers commissioned a report on the importance of site investigations (2004), which again emphasised the importance of using existing information. 
BGS holds large quantities of geological information, much of which is in digital form. Data are in the form of geological maps, tunnel maps, borehole logs, site investigation reports, water abstraction boreholes and geochemical samples, but how should this information be presented?

Currently the desk study is used to provide a 3D conceptual model of the subsurface, which ideally should be produced before the start of the site investigation phase of a project. However, this is usually created after or during ground investigation work rather than before (Culshaw, 2005). The notion that a conceptual model should be used to design the site investigation is discussed in detail by Fookes (1997) and Fookes et al. (2000). Here they argued that knowledge of the geology and geomorphology of a site could be used to indicate the ground conditions most likely to be encountered.

Current advances in the use of Geographical Information Systems (GIS) and 3D modelling software have meant that there is now a far greater opportunity to develop geo-environmental information systems for urban development that can take greater account of the third dimension. In the TGDZ this has lead to the development of the a 3D attributed geological model. This has moved us away from the conceptual ground models of Fookes (1997) to bring us a step closer to real ground models of Culshaw, (2005). This paper describes the steps taken to produce digital 3D geological models of the shallow subsurface attributed with property information, as part of a desk study to aid planning and site investigation design.

The key developments necessary for this idea to be taken up widely lie in improvements in 3D modelling capabilities, which, in turn, depend on the availability of digital data and on improvements in 3D modelling software (Turner, 2006). Critically, it is the ability to build and visualise 3D models on a standard desktop PC without the need for expensive and operationally complex computer software which will encourage the regular use of 3D models.

In recent years, data has become increasingly available in digital format (Bowie 2005, Jackson 2004). This has necessitated changes in data management practice (Turner 2003, Culshaw 2005), such as the requirement for data to be spatially registered in nationally recognised coordinate and elevation systems and the move towards corporate databases which have nationally agreed data standards and validation procedures (Baker and Giles 2000). Developments in 3D modelling technology mean that 3D models can be produced quickly 
and updated easily, a significant step forward from previous 3D modelling systems (Strange et al. 1998). Geological 3D models can also be supplied to planners and developers in either GIS compatible formats or within a 3D viewer, both of which can be viewed on a standard desktop PC (Royse et al. 2006a). Thus, such advances in 3D modelling technologies have now made the 3D geological model a practical option for site investigation work.

Once the 3D geological framework has been constructed, the physical attributes of the modelled geological units (3D polygons) can be described. This attributed geological model is now able to encapsulate, at least in part, some of the natural variability of real geological systems. Rosenbaum (2003) considered this to be one of the four major impediments to 3D modelling not being widely used within the geotechnical industry. The method of attribution described within this paper is not able to take into account the heterogeneity within a modelled geological unit (Group, Formation, Member or Bed) but rather it provides the user with bulk attributes for a given unit. This has been done for two reasons: firstly, the process of discretisation (whereby each modelled unit is split into a series of 'volume' elements, often cubes) results in very large data files being generated (Turner 2006), which are difficult to handle, making data manipulation on a standard desktop PC unworkable. Secondly, to model property variation within a geological unit without an unfeasibly high level of uncertainty, it is essential that geoscientific data is of a high density and quality throughout the modelled area. In the TGDZ, although a large amount of geoscientific data exists, the quality of the data is highly variable making modelling of 'within-unit heterogeneity' impracticable. Nevertheless, heterogeneity within a modelled unit can be visualised by using a variety of graphical techniques which will be discussed later in this paper.

A modelling system has been adopted at BGS which produces not only detailed 3D models (Howland, 2000, Strange et al. 1998), but models attributed with physical, chemical or hydrogeological parameters (fig 2). Once the attributed 3D model is completed a large number of customised geoscientific outputs can be generated with little computation. This paper will describe this system and outline some of the customised outputs which have been developed for the TGDZ.

\section{Fig. 2}




\section{D Geological modelling in the Thames Gateway}

The geological model of the TGDZ was constructed using proprietary software GSI3D (Geological Surveying and Investigations in 3 Dimensions), produced by Insight (Hinze et al. 1999; Sobisch 2000; Kessler et al. 2004) and described by Culshaw (2005). The main reason why many professionals do not use 3D modelling routinely is because many modelling packages are too complex (Hack et al. 2006). GSI3D gets around this problem by using traditional techniques of cross-sections and fence diagrams, together with a generalised vertical section (Fig 3, Kessler and Mathers, 2004).

\section{Fig. 3}

The Thames Gateway model has been built from over 4000 boreholes and over 200 northsouth and east-west trending cross-sections. The model was constructed using a generalised vertical section of the lithostratigraphy, which, when combined with the generated crosssections, created a fence diagram of the geology. The superficial and bedrock layers were then further constrained by the recent 1:10 000-scale digital geological mapping and the digital terrain model (DTM).

\section{Data sources}

The integrity of the 3D attributed geological model depends on having an array of accurately logged boreholes, good down-hole geophysics and access to other site investigation data at a sufficient density to allow geological units (including groups, formations, members or beds dependent on the level of detail required) to be modelled and their physical properties to be characterised with confidence.

\section{Geotechnical data}

Site investigation reports provided the primary source of geotechnical data in this study. The data was entered into the National Geotechnical Properties Database (NGPD), which follows the Association of Geotechnical and Geoenvironmental Specialists (AGS) digital format tables. The data is in an Access $₫$ database, which is backed up in Oracle $\subset$. The data is exported and usually manipulated in Excel@ C. This database contains geotechnical data from over 3200 boreholes and trial pits from the TGDZ. 


\section{Hydrogeological data}

Hydrogeological data incorporated into the model consisted of well and water borehole logs, borehole geophysical data and groundwater level surfaces and contour plots. Existing groundwater level surfaces or contour data used in this study were obtained from: January 1990 (Environment Agency, 1990), January 2004 (Environment Agency, 2004), 1965 (Ellison, 2004), “Pre-development” (Water Resources Board, 1972), and modelled groundwater levels for February 1995 and October 1997 (Jackson and Spink, 2004). The most useful dataset was the modelled groundwater levels of Jackson and Spink (2004) as these proved to be the most reliable and provided full coverage of the Thames Gateway model between Thurrock and Dartmouth, (a focus for hydrogeological attribution). Borehole data were collated from the BGS WellMaster database, the Swanscombe groundwater modelling project (Jackson et al. 2004), and from the Environment Agency.

Groundwater level data obtained from borehole logs proved to be limited within the area of interest and only 58 post-1980 groundwater levels could be identified in, or near to, the Thurrock-Dartford hydrogeological study area. Point data was used principally to highlight potential anomalies in the modelled groundwater level data.

\section{Attribution of the Thames Gateway 3D Geological Model}

To gain full value from the 3D geological model in the urban environment, attribution of the model with engineering geological and hydrological data is necessary. The 3D model is attributed by assigning property values for each geological unit modelled (be that Group, Formation, Member or Bed). Bulk attribution provides a way of visualising the property characteristics of each geological unit modelled and their spatial relationships. The TGDZ model has been attributed with several datasets including lithostratigraphy, engineering geological classification, ground water productivity and, maximum and minimum permeability.

\section{Engineering geology}

The 3D geological model provides a framework on which spatial presentation and interpretation of geotechnical data can be undertaken. From this, an engineering geological classification scheme can be formulated and then engineering geological ground conditions can be visualised in 3D space. The engineering geology attribution is based on the 
classification scheme developed in thematic mapping projects described above (Forster et al. 2004).

The geological units are primarily divided in terms of engineering 'rocks' and 'soils'. In the TGDZ, much of what is classified as bedrock by the geologist is classified as a soil by the engineer. The exception is the White Chalk Sub-Group, although the upper part is often weathered to a 'putty' chalk, which also, for engineering purposes, behaves as a 'soil'. These primary divisions are further subdivided into coarse-grained (sand and gravel), fine-grained (clay and silt), organic soils (peat) and mixed soils, (which contain discrete fine and coarse beds or mixtures of both). Most of the geological units classified as fine or coarse are, to some extent, mixed, for example the London Clay Formation, which is predominantly clay also contains beds of sand at some levels, and the Thanet Sand Formation, which predominantly consists of fine sand, may also contain beds of silt and clay. Secondary divisions further classify the modelled units on the basis of general strength or density. These subdivisions are based on log descriptions, undrained shear strength and standard penetration tests, plus any other appropriate parameters included in site investigation reports.

This description only provides an average value for each modelled formation. The majority of formations within the TGDZ display a significant amount of heterogeneity. To combat this, the 3D modeller can model the geological units at a higher resolution i.e. down to the member or bed level but this may not always be possible, in which case intra-formational variation can be displayed as either statistical plots or shown within borehole sticks. Strength or density data can easily be described within statistical plots or cross plots which can be attached via hot links to the attributed model. Figure 4 is an extended box and whisker plot showing the percentiles (Culshaw, 2005) of SPT N-values for the terrace gravel deposits. It shows that the majority of these deposits are medium dense to dense (that is SPT N-values of 10 to 30 and 30 to 50), with median values of about 30 .

\section{Fig. 4}

Figure 5 shows and Table 1 describes the 3D engineering geology attribution for the central part of the Thames Gateway.

\section{Table 1}




\section{Fig. 5}

\section{Hydrogeology}

Parameterising the 3D geological model enables the user to view and analyse the vertical and lateral variation in rock properties, rather than the variation in lithostratigraphy. For example, if the user wanted to identify high permeability units at depth, say for the assessment of aquifer storage and recovery potential, they can easily identify these units, their depth, thickness, and lateral extent, all of which can affect the prospects of a successful scheme.

For the Thames Gateway 3D model hydrogeological classification schemes for permeability indices (provides an indication of the range of permeability likely to be encountered for each geological unit) and permeability types were taken from the attributed 1:50 000-scale Digital Geological Map of Great Britain (DiGMapGB) table (Lewis et al. In press) and aquifer type was based on the Environment Agency's classification scheme for the Water Framework Directive (WFD). An example of a resultant model for part of the Thames Gateway model between Thurrock and Dartford is shown in figure 6. In this case the 3D model has been attributed to illustrate the Environment Agency’s WFD Aquifer Classification scheme. The 'exploded' view of the model allows the user to appreciate the relationship between the lithostratigraphical and hydrogeological units. By using the model in this way, a clearer understanding of the complexity and spatial variability of the lithological sequence within the Thames Gateway region can be gained. This provides a means for assessing the potential hydrological performance of any lithological sequence modelled. Furthermore, the model can be used to define accurately areas of recharge and discharge, which could be used to inform water resource management strategies at a regional and site specific level. The model can also be used to evaluate potential pollution pathways at the site scale; this is particularly useful when considering the potential pathways that new foundations may provide between surface and groundwater aquifers.

\section{Fig. 6}




\section{Applications of the Attributed Geological Model in the Thames Gateway Development Zone}

The resultant attributed geological model can then be used to predict not only the rock and soil types, but their vertical and lateral variation and also the variation in their engineering properties (such as rock strength, shrink-swell characteristics, compressibility etc), and hydrogeological properties (such as permeability, porosity etc). The model can also inform the user about general engineering geological and hydrogeological ground conditions, such as thickness of the unsaturated zone or the presence of perched water tables or the depth to good foundation conditions. The 3D geological model is now gaining the ability to encapsulate the natural variability of geological features (Turner 2006). Several examples of how the attributed TGDZ 3D model has been used to communicate geoscientifically complex ideas are presented.

\section{Displaying attributions at different depths}

Different surfaces other than the DTM can be used to 'slice' the model. For example, the piezometric surface can be used to create a map of the geology at the water surface. This is done by intersecting the surface with the geological model. By analysing such maps, much additional insight can be gained about the hydrogeological regime. It is then possible to understand visually where water levels are confined or unconfined.

It is also possible to slice the model at different depths below ground level. This has been done using the engineering geology classification in Figure 7 for surfaces at, $1 \mathrm{~m}, 5 \mathrm{~m}$ and 10 $\mathrm{m}$ below ground level. The resultant surfaces can be used to predict the presence or absence of problematic material, such as peat.

\section{Fig. 7}

\section{Presentation of borehole Information}

As described above, attribution of the model is confined currently to bulk properties of modelled units be that at the group or bed level. Variation of parameter values within a model unit cannot be shown by just using the model and have to be described as part of the attribute classification. Within this modelling system, it is possible to display variation by using 
'borehole sticks', which are correctly positioned within the model, in sections or within the 3D model (fig 8).

A wide range of data can be shown in this way, including: lithology, strength or density descriptions, weathering classification, water level data, geotechnical, geophysical and geochemical parameters. Each of these factors is classified and assigned a colour. A number of parameters may be shown together with the lithostratigraphy in adjacent 'borehole sticks,' such as lithology and geophysical logs. This may not suit all parameters as the classification in some cases, can reduce details required to make a valid interpretation. However, for a large proportion of geoscientific data, this provides a useful way of viewing intra-formational variability. A log showing temperature and conductivity variation with depth for borehole TQ47NE696 is shown in figure 9.

\section{Fig. 8}

\section{Fig. 9}

Another use of the 'borehole stick' method is in displaying groundwater level data obtained from borehole records. A minimum and maximum water level was obtained from borehole records and the data displayed as 'borehole sticks'. This method provides a clear indication of the position of the water table when plotted in conjunction with geological cross-sections or fence diagrams. The water level data can then be displayed together with the geological model.

\section{Geotechnical and engineering applications}

Engineers and geologists can use the model for different purposes: to assist in the recognition and identification of problematic ground conditions; as a tool to aid in the planning process; to help locate ground investigations and to ensure that the most economical and valuable information is obtained from ground surveys.

Exstension of construction onto sites on, or near, the River Thames floodplain will necessitate an understanding and consideration of the geological and physical properties of the alluvium and peat. In general, the alluvium and peat are of very low to low strength (Anon., 2004) and also, their strength does not increase significantly with depth. The low strength and, therefore, 
high (and potentially uneven) settlement provides poor foundation conditions, restricting the foundation type and loading that can be applied.

The engineering classification (Table 1) applied to the 3D attributed model reflects these properties and therefore the model can be used to assess the suitability of each geological unit within the modelled area for use as a founding material. In the case of the Thames flood plain, the best geological units on which to establish foundations are: the Taplow, Kempton Park and Shepperton Gravels formations, or the White Chalk Sub-group.

The 3D attributed model can also be used to provide information on the depth to founding material, its properties and the variability of these properties. The depth to the top of the gravel formations and Chalk beneath the alluvium can be exported from the 3D model and displayed as depth or thickness (isopac) contour plots in ArcGIS (Figures 10). It is then possible to combine the 3D surfaces with other spatially rectified data (be that geotechnical, geochemical, or geographical etc) which, when combined together, provides a way of assessing the suitability of sites for a variety of construction techniques.

The 3D attributed geological model can also be used to generate engineering geological crosssections along a given linear route, such as a railway track, road or flood defence barrier. Spatial attribution of geotechnical data and simple methods to recast sections in engineering geological terms are easily realised using these new techniques. A simple visual inspection of Figure 11 allows regions of potentially difficult ground conditions to be immediately identified. It is now not sufficient to identify fine-grained soils as locations for potentially problematic ground conditions, as was done in the past using a traditional geological map. Much more information is required about the geological structure, lithological variability, mineralogy, moisture content and geotechnical properties of the rocks and soils, much of which can be supplied by emerging 3D geospatial databases. These databases can be interrogated at key depths (as shown above) providing an indication of the wide variability of geological materials and conditions beneath the ground surface. Detailed geological sections along linear routes can be modelled and the locations of potential problematic rocks and soils, such as alluvium and peats, can be identified (Figure 11). Such attributed sections could become a key tool in strategic infrastructure (e.g. pipelines, roads and railways) maintenance and network expansion plans.

\section{Fig. 10}




\section{Fig. 11}

\section{Hydrogeological applications}

The Thames Gateway 3D attributed geological model can be used as a framework to help develop a conceptual model of the hydrogeological system essential in understanding water movement and pollution transport.

The starting point for any hydrogeological conceptual model is a description of the geology so it follows that, to improve the conceptual hydrogeological model, geological knowledge and understanding must be improved first. The advantage of a 3D model is that geological and hydrogeological information can be viewed simultaneously providing the hydrogeologist with the tools necessary to incorporate more detailed geological information into the groundwater model.

Groundwater level data can be difficult to use, partly because of its limited availability in digital format and partly due to the dynamic nature of groundwater levels. In the unconfined Chalk, groundwater levels may vary by tens of metres per year. In the London Basin, there is the additional problem that groundwater levels were depressed for decades due to abstraction, but since the 1960s have been recovering. Thus, one of the starting points was to examine the available groundwater information and decide on the most appropriate data to use. For the initial development of the model, the output from a groundwater flow model was used. This will be replaced in the longer term as new groundwater datasets become available digitally.

Once the groundwater surface has been calculated, it can be added into the model. In this way, the relationships between the groundwater level (potentiometric) surface, geological horizons and the land surface can be easily visualised. This further aids the development of the hydrogeological conceptual model, for example, by identifying higher permeability horizons, within which the groundwater surface is constrained. It may also serve as a check on the potentiometric surface, identifying areas where the contour data or interpolation is incorrect. Displaying the potentiometric surface together with the DTM allows potential areas of flooding to be delineated.

The simulated groundwater level surface for February 1995 is shown together with the DTM (Fig. 12). This clearly indicates the relationship of the groundwater surface with the land 
surface, for example, its relationship to the various marshes along the banks of the River Thames and the intersection of the water table with Eastern Quarry, a large chalk quarry to the south of the Thames. This model can also be used to delineate and visualise areas at risk from groundwater flooding, for example, where the potentiometric surface is close to the land surface.

\section{Fig. 12}

The natural development of karst features in the Chalk is known to be related to Chalk lithology and proximity to the potentiometric surface (Farrant, 2001). Using a 3D model containing detailed Chalk lithostratigraphy (Bristow et al. 1997) it is possible to highlight zones which would favour conduit development, such as the boundary between the Seaford and Lewes Nodular Chalk. Such areas can develop extensive natural cave systems, such as at Strood Waterworks (TQ729693) in the TGDZ, where a 60 m natural cavern was discovered during tunnelling works in 1879 (Bradshaw et al. 1991). Using the attributed geological 3D model in this way will improve understanding of the groundwater flow regime, resulting in improvements in the protection of existing groundwater abstractions and the development of new abstraction boreholes.

For the area around Thurrock in the north and Swanscombe in the south, the geological map at the potentiometric surface indicates that the Chalk aquifer is confined in the north but unconfined in the south. By creating maps for a high and low water level, it is possible to identify where water levels have the greatest range of fluctuation, which may be a result of pumping, recharge or the properties of the aquifer itself. This type of analysis identifies the anomalous areas and provides input into the conceptual hydrogeological model.

The 3D model could also be used to assess the risk of a new development contaminating the local groundwater supplies. Contamination studies concentrate on the linkages between source and receptor. The 3D model can be used to assess these potential links. An example of this is the Lower Lea Valley. Here, thick sequences of superficial deposits comprising River Terrace Gravels and Alluvium are underlain by Palaeogene deposits of the London Clay Formation with the Lambeth Group below. A detailed description is given by Ellison et al. (2004). Where the London Clay is absent and the superficial deposits rest on the Lambeth Group (which consists of interbedded layers of clay and sand) for example, near Stratford Marsh, there are significant implications for the development of pathways from the surface to 
the Chalk aquifer. As the Lambeth Group is extremely variable, it is likely that, at some locations, the clay layers may be thin or absent; consequently, the Chalk aquifer will be partially or wholly unconfined, that is, unprotected at these localities. A similar situation occurs in the Kempton Park gravels where irregularities in the rockhead surface (scour hollows) are known to exist (Berry 1979). The scour hollows can be as much as $15 \mathrm{~m}$ in depth; in these instances, the scouring will have removed the clay layers from within the Lambeth Group and, as a result, a direct pathway is established between surface water and the Chalk aquifer. By using the 3D geological model it is possible to locate sites where these situations are likely to occur and hence, at an early stage, identify these potentially problematical ground conditions.

\section{Confidence attribution}

Confidence or uncertainty modelling provides a way of visualising the differences between a digital representation and the real phenomenon. Shallow subsurface modelling, in particular, requires a high level of feature resolution; more precise property matching and the ability to differentiate conditions in a noisy environment (Rosenbaum, 2003) make the differences between the digital representation (the 3D model) and reality more acute. If the 3D attributed geological model is to be used to plan ground investigations, then effort is required to provide the user with the means to assess the accuracy of the model. The key issue here is in the certainty that can be placed on the spatial position of a given modelled horizon. As these models can be used by a far wider group of users than was traditionally the case for the 2D paper map, it is essential that confidence is expressed clearly (Culshaw, 2005). According to Evans (2003), there are two areas of uncertainty: firstly those associated with the data and measurements themselves and secondly, those inherent to the modelling process.

In trying to understand confidence and then to find a way to semi-quantify and visualise it, where the lack of certainty is located within our model must be identified. The way this is done is to construct a cause and effect diagram or Fish Diagram (Kindlarski 1984). Once done, it is then necessary to quantify certainty in such a way that users can easily understand it. In the case of the 3D geological models produced in the TGDZ, it was found that there are three main issues that will adversely affect the confidence of a model: data quality, data quantity and geological complexity. This is supported by work undertaken by Cave and Wood (2003) where they looked at the uncertainty of geological modelled surfaces and carried out a 
bootstrap re-sampling exercise on the data (Chernick 1999). They found that the mathematically calculated error was close to the true error in the data. They also showed that areas of greatest uncertainty were related to areas which lacked data points or where the shape of the surface is changing rapidly (in other words where the geology is unpredictable).

Clarke (2004) discussed a process for assigning confidence to geological interpretations and the assessment of geological complexity. He produced a generic confidence evaluation scheme for the geological interpretation and assessment of complexity. The geology of the TGDZ is a relatively simple layer cake system, which means that sources of error caused by geological complexity in this case generally can be limited to certain lithostratigraphical interfaces such as the base of the gravels beneath the alluvium and above the bedrock.

In the assessment, each piece of data used to model each surface was given a confidence value as to its quality on a scale of 1 to 10 (10 being excellent and 1 being very poor). This included borehole data, geological map data and cross-sections which were drawn up during the course of the modelling process. The geological map data and cross-section lines at this point were converted into point data (at spacing appropriate to the project) so that accurate quality values could be assigned. For example, geological line work for bedrock that is covered in superficial deposits is generally less accurate than bedrock geology lines where little or no superficial cover exists.

The data were then collected together for each modelled surface. It was necessary to add null values across the modelled area where there were no data. To have a regular spread of null points at an appropriate cell size, a grid was generated and null values added where no modelled data were present. The data were then interpolated using an inverse distance weighted technique (Shepard 1968) and cut to outcrop.

The resulting grids display a confidence range for each boundary surface within the model (Fig. 13). These grids can be displayed within a GIS or a 3D modelling package alongside the modelled surfaces. The grids graphically portray, to a large extent, what a trained geologist identifies as a matter of course. This lends further credence to the technique used and provides a simple but structured method for displaying, to both clients and the public, the confidence range for each surface.

Fig. 13 
The method demonstrated here is not entirely objective and does not rely totally on mathematical calculations. However, It does, rely heavily on the subjective input from the interpreter, particularly in the assessment of quality. Therefore it is essential that the assessment of data quality is done concurrently with data collection. Retrospective confidence assessments have been found to be both time-consuming and less reliable (Clarke 2004).

The use of attributed 3D models in decision-making results in models being used to make predications as to the likely condition of the shallow subsurface at a particular site. Any such prediction will have an element of uncertainty and risk attached to it (Turner 2006). The generation of the 3D model in itself requires an element of prediction between known data points. Consequently, uncertainty modelling is an integral part of the 3D attributed modelling process. The simple method suggested here allows for a record of the uncertainty within the modelling procedure to be documented and provides a way to present the results visually to potential users.

\section{Summary and Conclusions}

The main failing of the traditional geological map, whether in its paper or digital form, is that it requires the user to have an understanding of geoscientific principles. Increasingly, there is a need for people from outside the traditional geoscientific user community to have access to geological information (Culshaw 2003). This has necessitated a change in the way that geoscientific data are displayed and interpreted, resulting in the construction of the 3D attributed geological model. The benefit of the attributed geological model over the more traditional geological map is that it allows the user to visualise the complex relationships between geological formations and units, to observe how, for example, the piezometric surface and geology interact and to appreciate the link between the physical characteristics of each formation or unit.

The value in having large quantities of geoscientific information, as is the case in the TGDZ, is not in the possession of it, but in the interpretation and presentation of that data to those that need it most. One way of achieving this is by adopting a modelling system such as described here, whereby not only are detailed and regional 3D models produced (Howland, 2000; Strange et al. 1998) but models attributed with physical, chemical or hydrogeological parameters. Once the attributed model has been created, it is possible to generate a large number of customised geoscientific outputs with little extra computation. 
Rosenbaum (2003) suggested that there were four reasons why 3D geological models of the shallow subsurface were not used routinely for site investigation design. These can be summarised below as:

- The lack of 3D and 4D mathematical, cognitive and statistical spatial tools

- The lack of modelling tools specifically designed for shallow subsurface modelling which are not too expensive and do not require specialist personnel to operate them

- The inability of models to depict accurately the natural variability of geological systems or to represent uncertainty

- The worry that the investment in time and effort to produce 3D models would not result in significant improvements in knowledge or better science

Since Rosenbaum listed his concerns the development of the 3D attributed geological model of the shallow subsurface has moved a significant step forward towards reaching his goals. The key development necessary for models of the shallow subsurface to be used routinely in planning and site investigation design lies in the ability to build and visualise 3D models on a standard desktop PC without the need for expensive and operationally complex computer software. Not only can the modelling system used here (GSI3D) be used on a standard desktop PC but also the 3D model is built by using traditional geological techniques which are familiar to geologists, engineering geologists and hydrogeologists, negating the need for specialist operators.

The attributed 3D model provides a platform whereby the integration and visualisation of data from many different sub-disciplines can be achieved. This allows the model to portray some of the natural heterogeneity of real geological systems. The level of geological detail contained within the model will always be dependent on the amount and quality of the digital data available, as is the case in the examples given in this paper. Nonetheless, it has been have shown that a considerable amount can be accomplished by bulk attribution of a geological model, whereby an understanding can be gained about general geotechnical, geological and hydrogeological ground conditions, such as thickness of the unsaturated zone or the presence of perched water tables or the depth to good foundations. Also, it has been shown that by simply incorporating a wide variety of hydrogeological information into the 3D geological model, it is possible to improve understanding and knowledge of the groundwater system and 
develop a better conceptual hydrogeological model for part of the TGDZ. Further work is needed to model the full heterogeneity displayed within real geological systems; nevertheless, it is possible to portray intra-formational variability by using statistical plots or 'boreholesticks' spatially registered within the model.

All users of digital geoscience data, in particular 3D models, must understand the limitations of the data on which they base their assessments. This is becoming more critical as improvements in 3D modelling techniques are allowing geoscientists to introduce a far greater level of realism into their models. Therefore it is essential, , that users of these data can differentiate between observed and conjectural information. This is often referred to as the inherent uncertainty of a digital 3D model and the geoscientific datasets on which it is based. There are still difficulties in the presentation of uncertainty calculations, making the resulting graphical representations difficult to interpret and use (Clarke 2004). However, a simple method for determining the uncertainty within a model has been outlined, which can be used alongside the attributed geological model, to provide a clearer picture as to the validity of the model. Users, ultimately, will need to be able to assess the risk associated with using these models, so that sound judgments can be made.

In summary, the 3D attributed geological models will transform the way geological maps are made and produced and change the way groundwater modelling and ground investigations are carried out. For example, site investigations will become more targeted, concentrating on areas where the engineering or hydrogeological behaviour is known to be complex or where there is little data. As a result, the future proposed by Culshaw (2005), where ground investigations will start by testing the validity of a 'real' geological model, is rapidly becoming a reality.

\section{Acknowledgements}

This paper is published with the permission of the Executive Director of the British Geological Survey (NERC) 
Table 1. Engineering geological character of the surface geology in the Thames Gateway area.

\begin{tabular}{|c|c|c|c|c|}
\hline \multicolumn{2}{|c|}{ ENGINEERING UNIT } & GEOLOGICAL UNIT & CHARACTERISTICS & ENGINEERING CONSIDERATION \\
\hline \multicolumn{5}{|c|}{ SOIL } \\
\hline \multicolumn{2}{|l|}{ Organic } & Peat & $\begin{array}{l}\text { Very soft to firm, fibrous or amorphous dark } \\
\text { brown, or black clayey PEAT occasionally woody } \\
\text { or with layers of shells. }\end{array}$ & $\begin{array}{l}\text { Highly compressible, even light foundation will be subject to variable and } \\
\text { considerable settlement over long periods. Dewatering produces } \\
\text { considerable and prolonged settlement. May produce acidic groundwater. }\end{array}$ \\
\hline \multirow[t]{3}{*}{$\begin{array}{l}\text { Mixed } \\
\text { Soils }\end{array}$} & $\begin{array}{l}\text { soft to stiff// } \\
\text { loose dense }\end{array}$ & $\begin{array}{l}\text { Worked and Made } \\
\text { Ground }\end{array}$ & $\begin{array}{l}\text { Highly variable, very soft to stiff, uncompact to } \\
\text { compact, loose to dense, CL.AY, SILT, SAND, } \\
\text { GRAVEL and COBBLE, may include man made } \\
\text { materials. May be compacted. }\end{array}$ & $\begin{array}{l}\text { Highly variable ground conditions, depending on content and whether it is } \\
\text { engineered. May be contaminated. May produce explosive or noxious } \\
\text { gasses. }\end{array}$ \\
\hline & Stiff/dense & $\begin{array}{l}\text { Engineered } \\
\text { Embankments }\end{array}$ & $\begin{array}{l}\text { Highly variable generally stiff or dense compacted } \\
\text { CLAY, SILT, SAND, GRAVEL, may include man } \\
\text { made materials. Compacted }\end{array}$ & Mostly suitable for foundations depending on construction methods. \\
\hline & $\begin{array}{l}\text { Firm to hard/ } \\
\text { dense to very } \\
\text { dense/ weak }\end{array}$ & $\begin{array}{l}\text { Lambeth Group and } \\
\text { Harwich Formation }\end{array}$ & $\begin{array}{l}\text { Highly variable lithologies, firm to hard CL.AY } \\
\text { occasional weak CLAYSTONE, compact SILT, } \\
\text { dense to very dense SAND and/or flint GRAVEL. } \\
\text { some shelly or SHELLL beds, occasional weak } \\
\text { limestone, occasionally organic. Lithological } \\
\text { variation often unpredictable. }\end{array}$ & $\begin{array}{l}\text { Generally good foundation material, however the lithological variability } \\
\text { gives rise to variable groundwater conditions including lenticular water } \\
\text { bearing sands. Variability provides difficult to very difficult tunnelling } \\
\text { and deep excavation conditions. Fissuring in clays may affect the stability } \\
\text { of cuttings. }\end{array}$ \\
\hline \multirow[t]{3}{*}{ Fine } & $\begin{array}{l}\text { Very soft to } \\
\text { firm }\end{array}$ & Alluvium & $\begin{array}{l}\text { Very soft to soft sometimes firm, sometimes } \\
\text { laminated, often organic, sometimes with shelly } \\
\text { CLAY. Top } 2 \text { to } 3 \text { metres may be firm to stiff due } \\
\text { to desiccation. }\end{array}$ & $\begin{array}{l}\text { Generally highly compressible, bearing capacities less than } 100 \mathrm{kPa} \text {. } \\
\text { Light foundation may be subject to variable and considerable settlement } \\
\text { over long periods. Dewatering produces considerable and prolonged } \\
\text { settlement. }\end{array}$ \\
\hline & $\begin{array}{l}\text { Uncompact } \\
\text { /compact }\end{array}$ & $\begin{array}{l}\text { Crayford Silt Ilford Silt } \\
\text { Formations }\end{array}$ & $\begin{array}{l}\text { Uncompact to compact often with vertical fissure, } \\
\text { SILT or firm CL.AY }\end{array}$ & $\begin{array}{l}\text { Some parts have high porosity and open structure which may be prone to } \\
\text { collapse on loading and wetting. Generally well drained, used in the } \\
\text { manufacture of bricks (hence 'brickearth'), excellent agricultural land. }\end{array}$ \\
\hline & $\begin{array}{l}\text { Firm to very } \\
\text { stiff }\end{array}$ & London Clay Formation & $\begin{array}{l}\text { Firm to stiff becoming very stiff or hard at depth, } \\
\text { near surface generally fissured, brown often with } \\
\text { gypsum otherwise grey, CLAY sometimes compact } \\
\text { SILT, occasionally dense to very dense SAND. }\end{array}$ & $\begin{array}{l}\text { Near surface prone to shrink/swell affecting shallow foundations. Planting } \\
\text { or removal of trees near buildings may exacerbate this. Depth of } \\
\text { weathering and fissuring varies. }\end{array}$ \\
\hline \multirow[t]{2}{*}{ Coarse } & $\begin{array}{l}\text { Moderately } \\
\text { dense to } \\
\text { dense }\end{array}$ & $\begin{array}{l}\text { Shepperton, Kempton } \\
\text { Park, Taplow, Hackney } \\
\text { and Lynch Hill Gravels } \\
\text { Formations }\end{array}$ & $\begin{array}{l}\text { Generally moderately dense to dense, sometimes } \\
\text { very dense SAND or GRAVEL or mixture of the } \\
\text { two, sometimes silty or clayey with local lenses of } \\
\text { silt, clay or peat. }\end{array}$ & $\begin{array}{l}\text { Generally good foundation condition. Excavations may require } \\
\text { dewatering and are generally unstable. High water table in excavations } \\
\text { may lead to running sand conditions. }\end{array}$ \\
\hline & Very dense & Thanet Sand Formation & $\begin{array}{l}\text { Very dense, slightly silty or clayey to silty to } \\
\text { clayey fine SAND, with gravel to cobble flint at } \\
\text { base (Bullhead Beds). }\end{array}$ & $\begin{array}{l}\text { Generally high bearing capacity but may be lower near surface where } \\
\text { weathered/cryoturbated. Requires dewatering in tunnelling and deeper } \\
\text { excavation. Water pressures often artesian where this formation is below } \\
\text { clay. }\end{array}$ \\
\hline \multicolumn{5}{|r|}{ Ulay. } \\
\hline Chalk & Comminuted & $\begin{array}{l}\text { Sleaford and } \\
\text { Newhaven Formations }\end{array}$ & $\begin{array}{l}\text { Comminuted to high density CHALK, } \\
\text { variable weathering depth, sometimes karstic. }\end{array}$ & $\begin{array}{l}\text { Depends on degree and depth of weathering and the presence of karst. } \\
\text { Bearing capacity generally good where not highly weathered, however } \\
\text { both bored and driven piles have little friction. }\end{array}$ \\
\hline
\end{tabular}




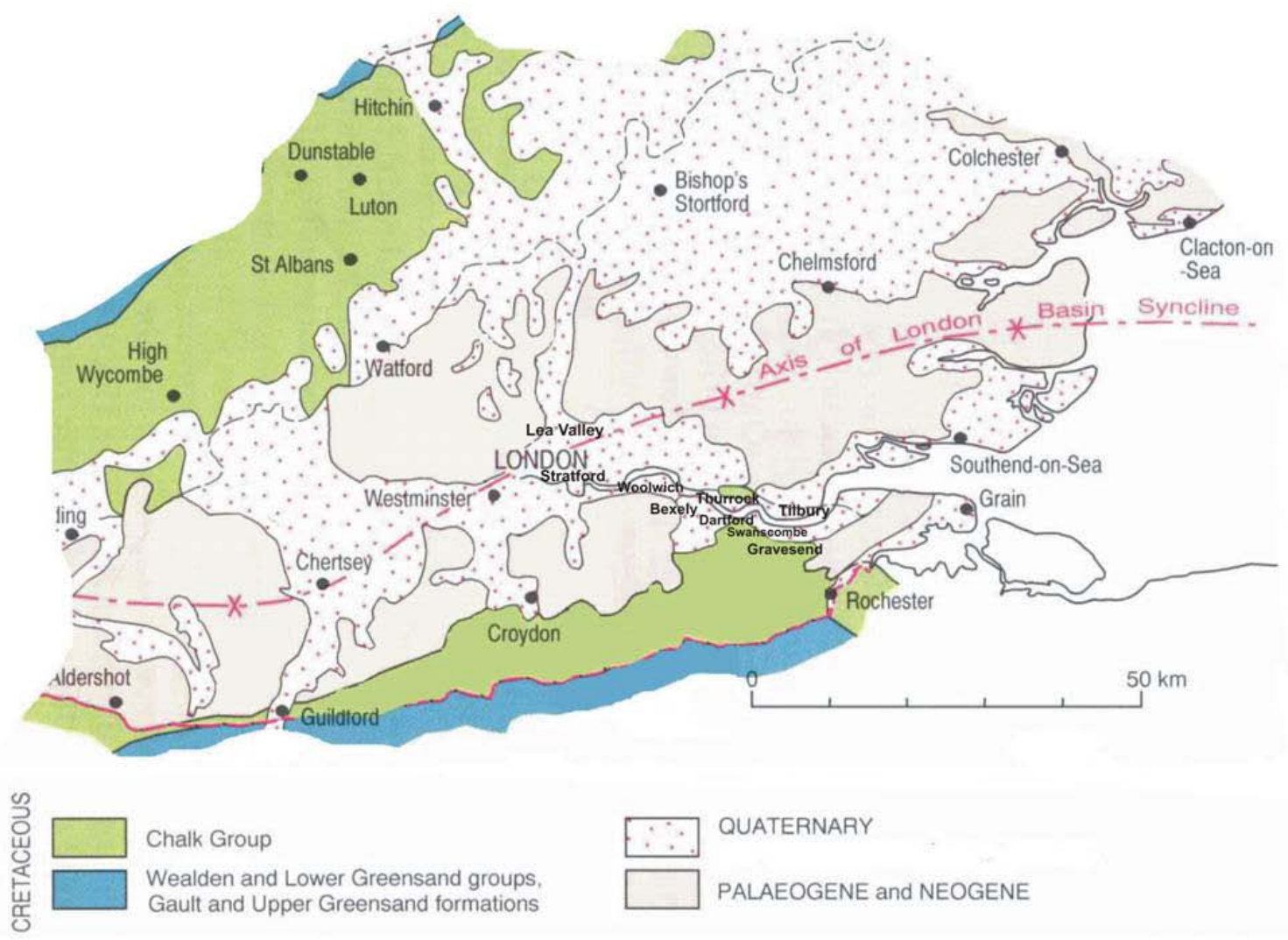

Figure 1. Geological Map of London and the surrounding area.

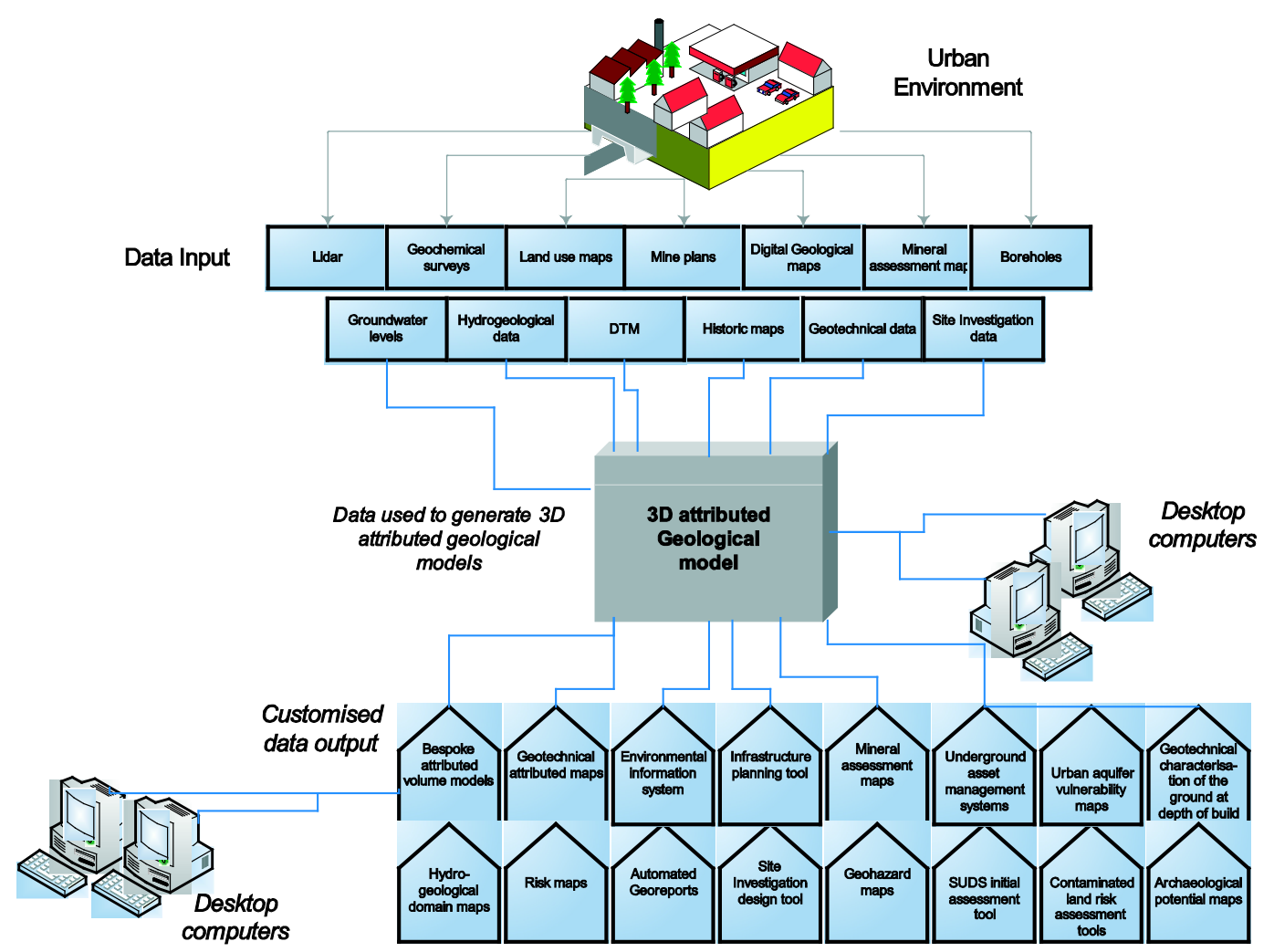

Figure 2. Flow diagram showing the process of building and applications of the 3D attributed geological model. 


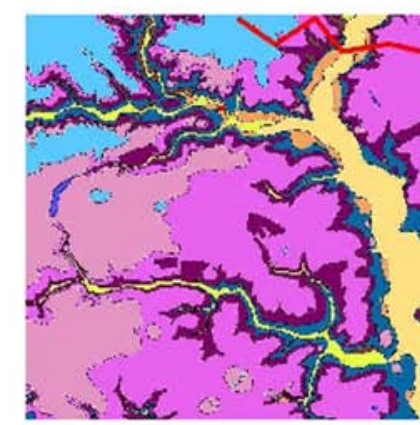

a) Map

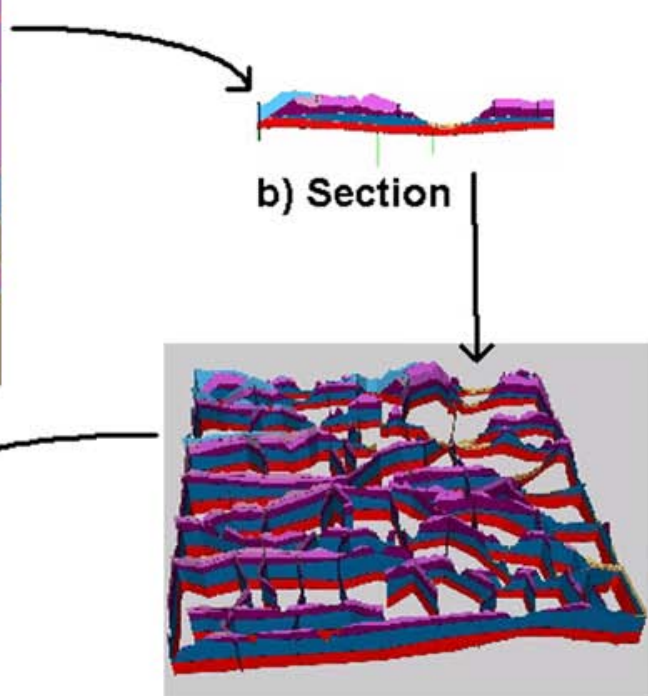

c) Fence diagram

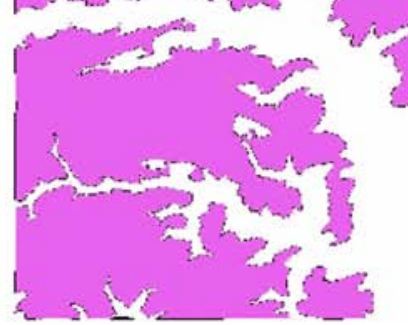

d) Unit distribution
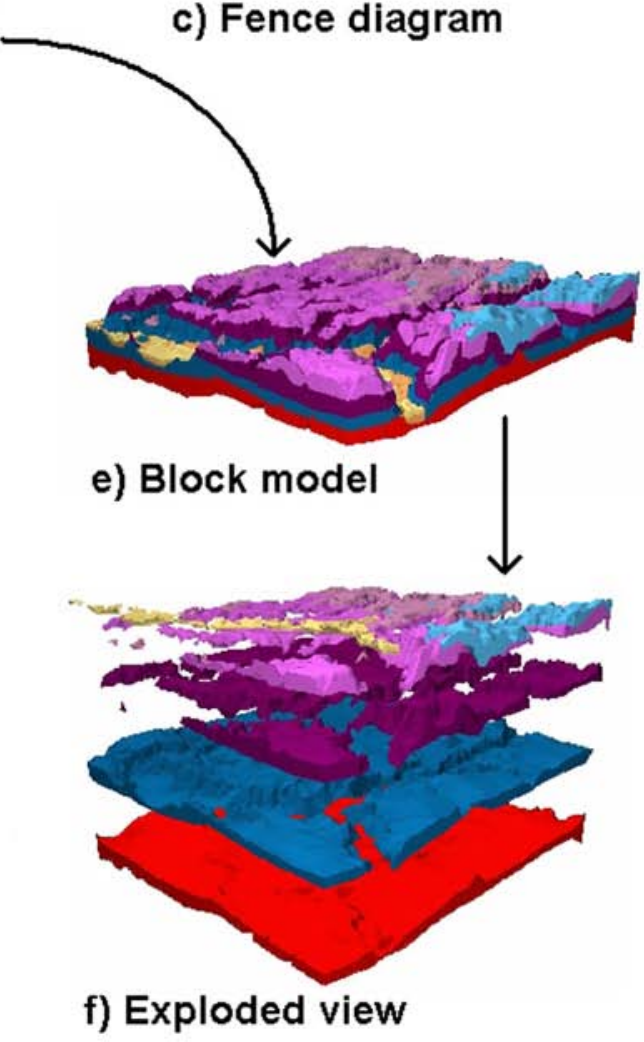

Figure 3. 3D geological model building work flow in GIS3D (after Kessler and Mathers, 2004). 


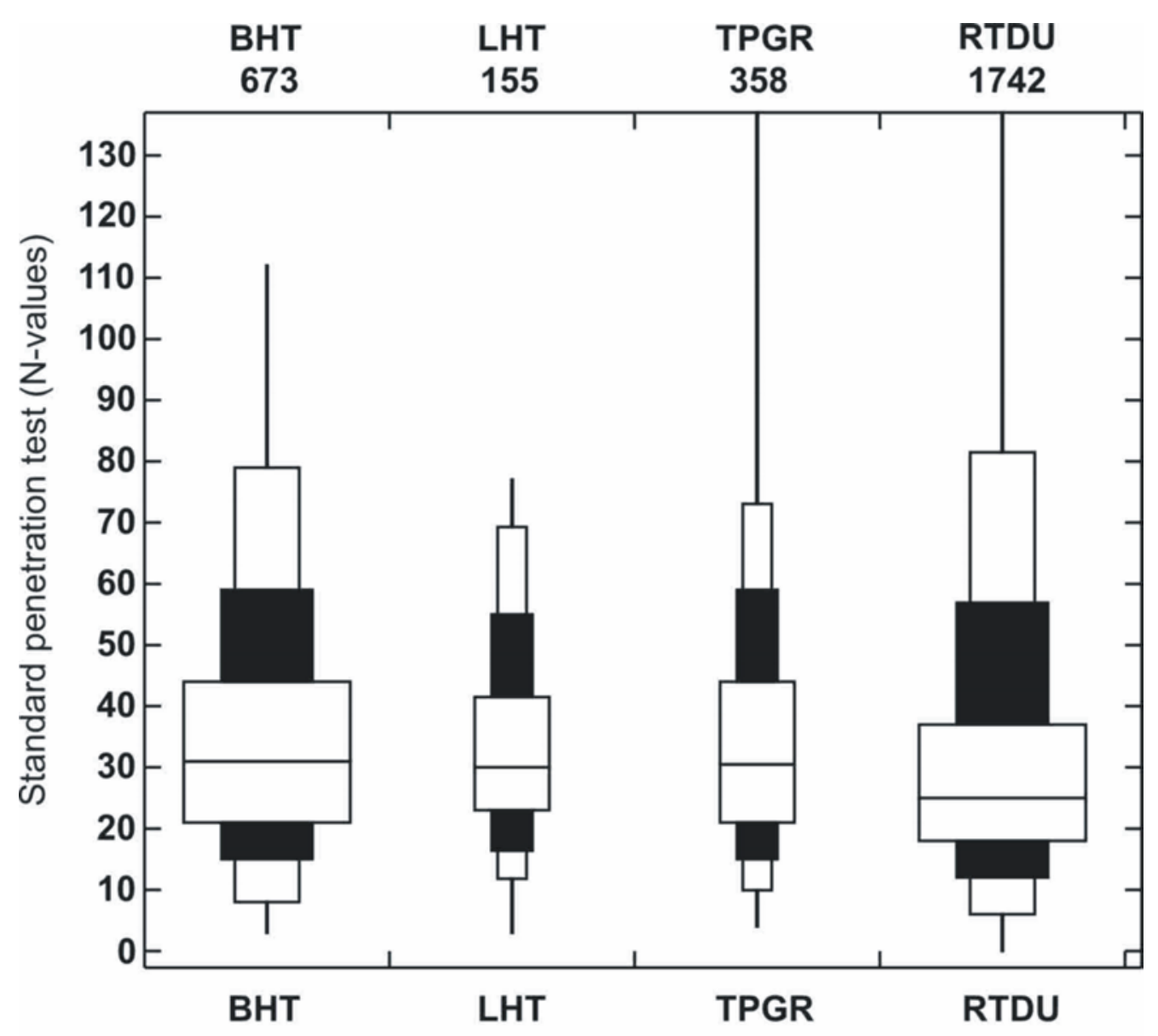

Figure 4. Box and Whisker plot of standard penetration test results for the terrace gravels in part of the Thames Gateway area. Where BHT = Boyne Hill Gravel Formation; LHT= Lynch Hill Gravel Formation, TPGR = Taplow Gravel Formation and RTDU $=$ Kempton Park and Shepperton Gravel formations.

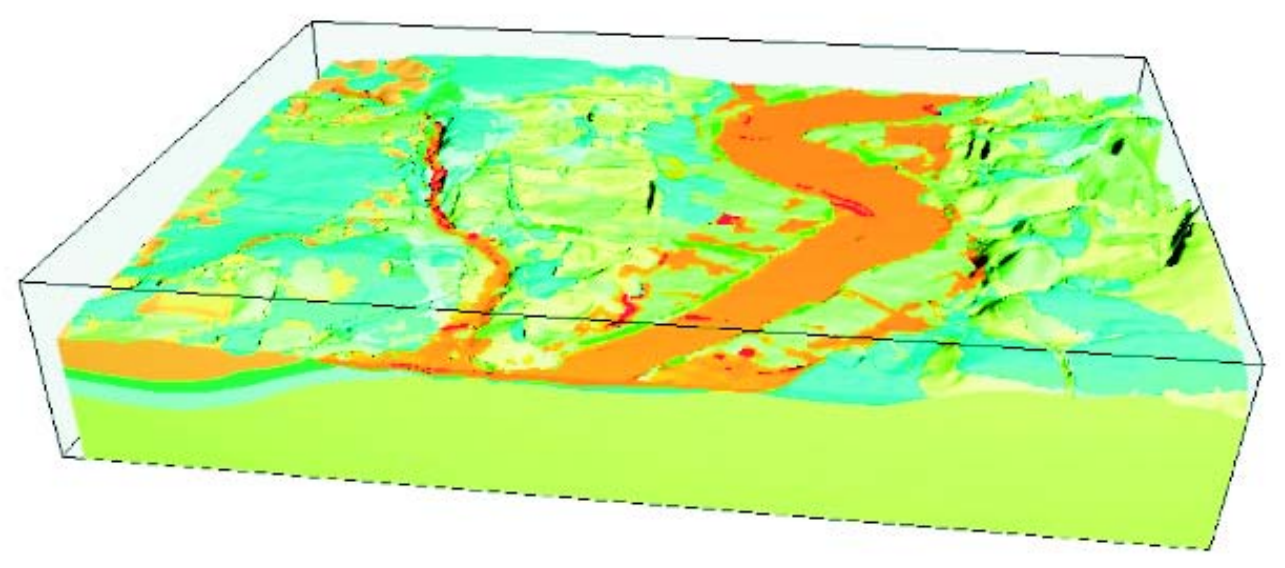

Figure 5. 3D block model of the engineering geological classification of the area between Dartford and Thurrock (see Table 1 for key). 


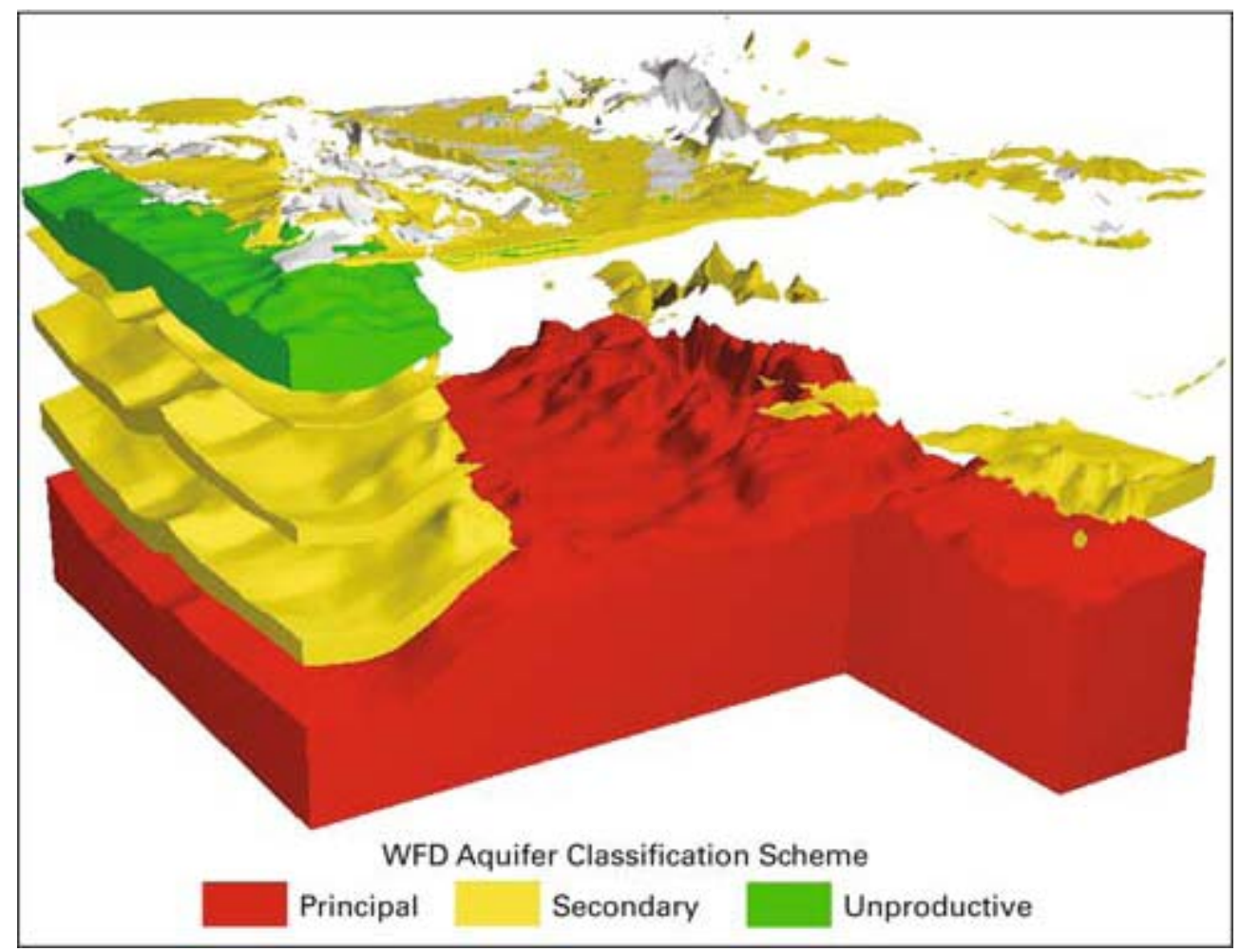

Figure 6. Exploded volume model illustrating the EA’s WFD aquifer classification scheme.

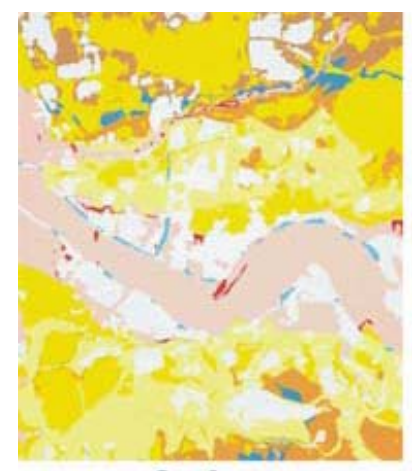

Surface

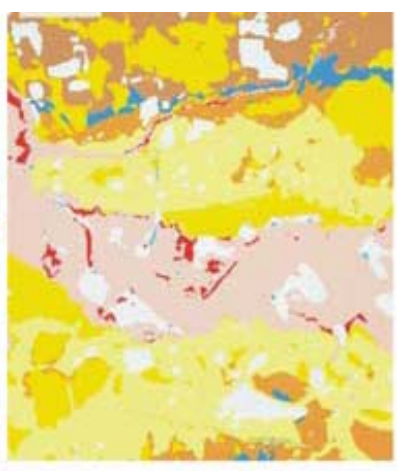

$1 \mathrm{~m}$ below Surface

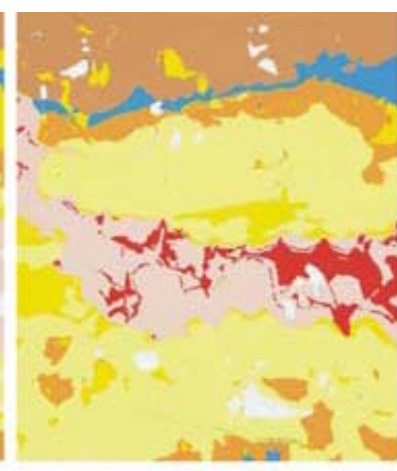

$5 \mathrm{~m}$ below

Surface

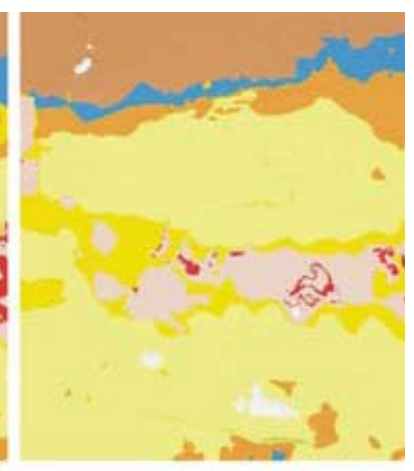

$10 \mathrm{~m}$ below Surface

Figure 7. Engineering characteristics at ground surface, and $1 \mathrm{~m}, 5 \mathrm{~m}$ and $10 \mathrm{~m}$ below ground surface. See Table 5 for key. 


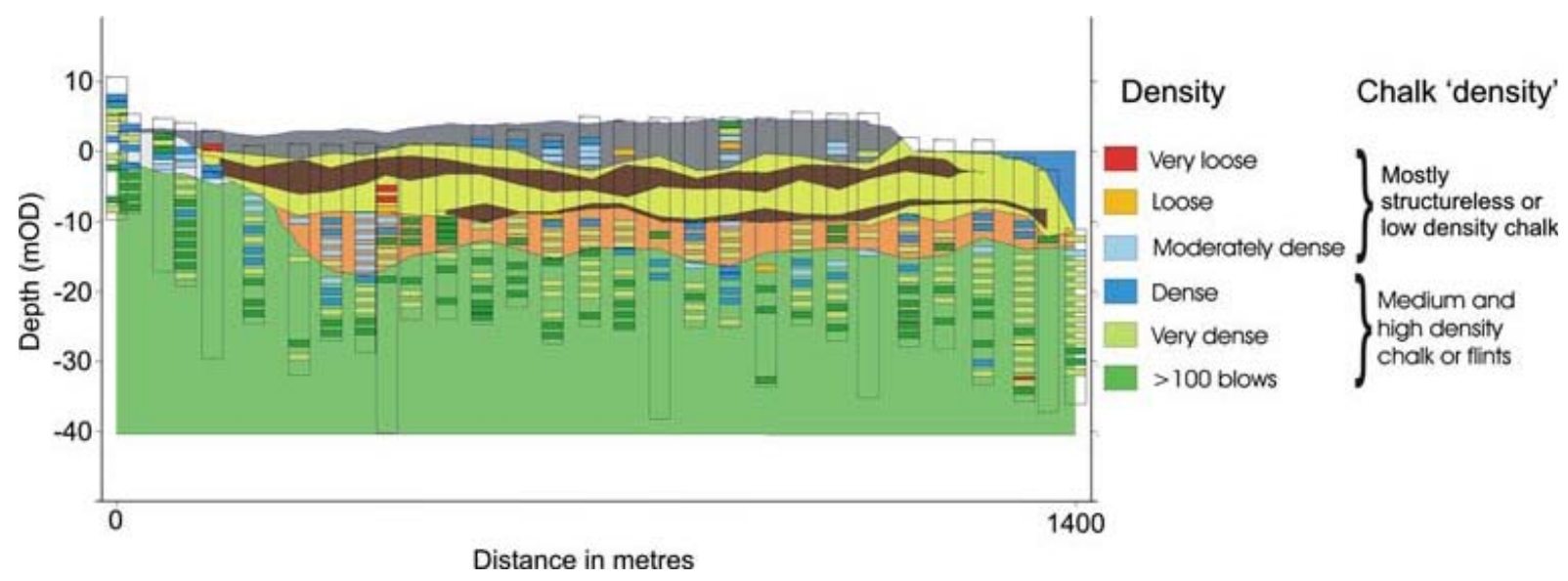

Figure 8. Cross-section showing the variation of SPT values within the Thames Gravels and Chalk within grid square TQ57NW.

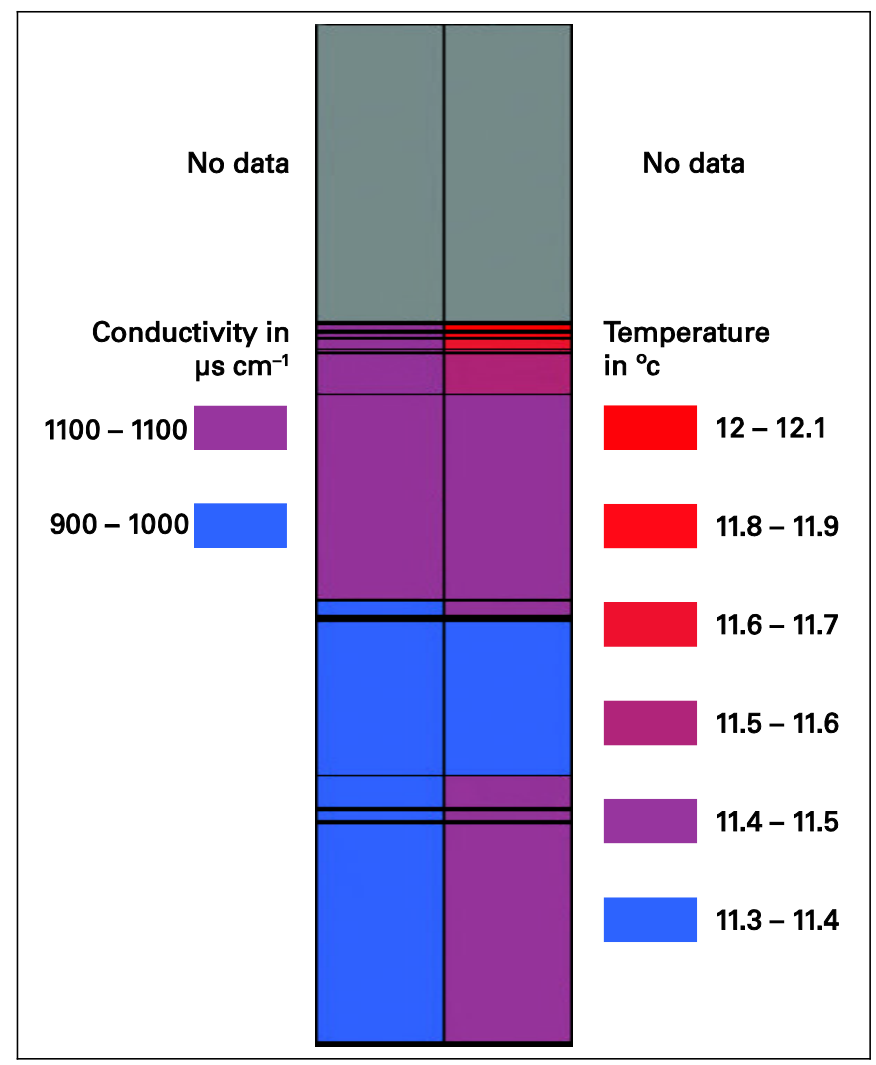

Figure 9. Temperature and conductivity log for borehole TQ57SW29 (GR 551800, 174800). 


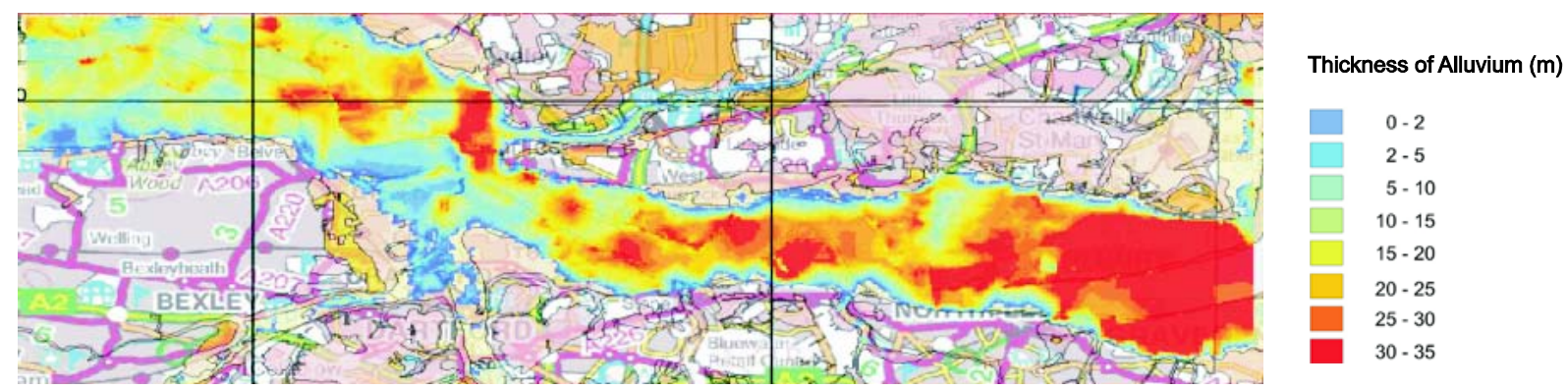

Figure 10. 3D geological model of the Lower Lea Valley, Stratford, London with automatically generated geological, and engineering geological cross-sections through the middle of the Lower Lea Valley.

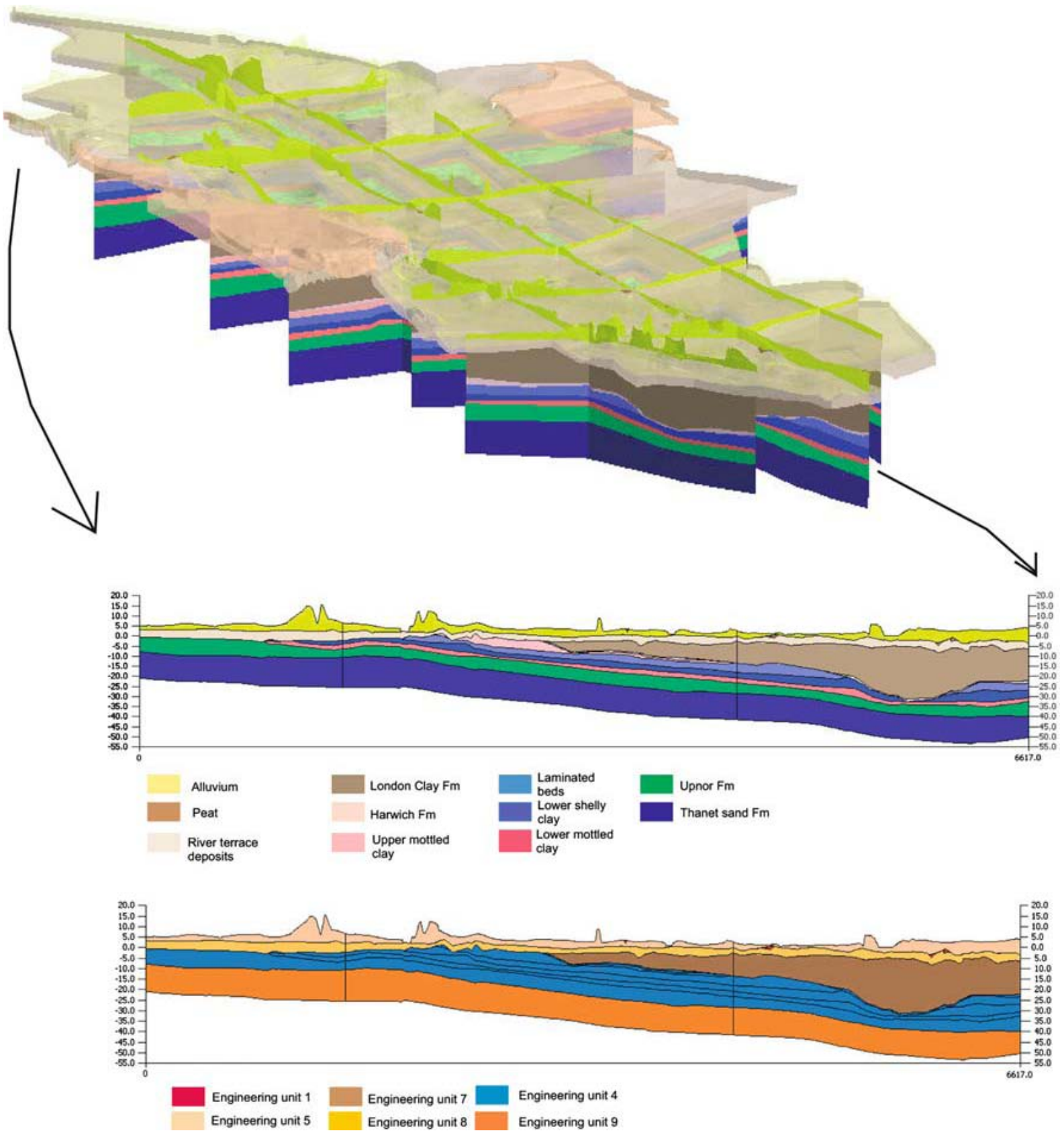

Figure 11. Contour map of the thickness of the alluvium between Bexley and Tilbury displayed in ArcGIS generated from the 3D geological model. 


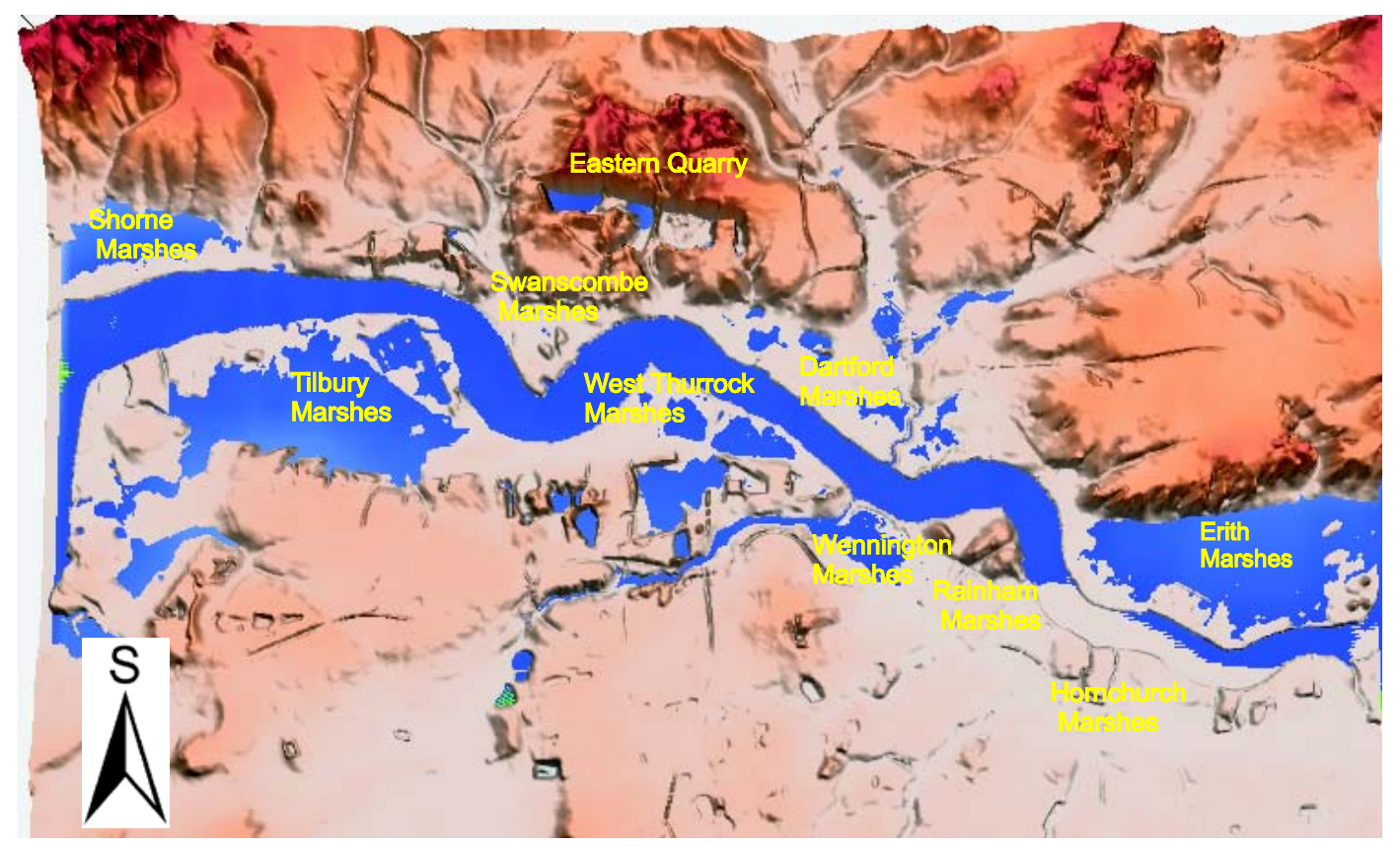

Figure 12. Intersection of simulated groundwater table for February 1995 (blue) with DTM within the West Thurrock area. 
A
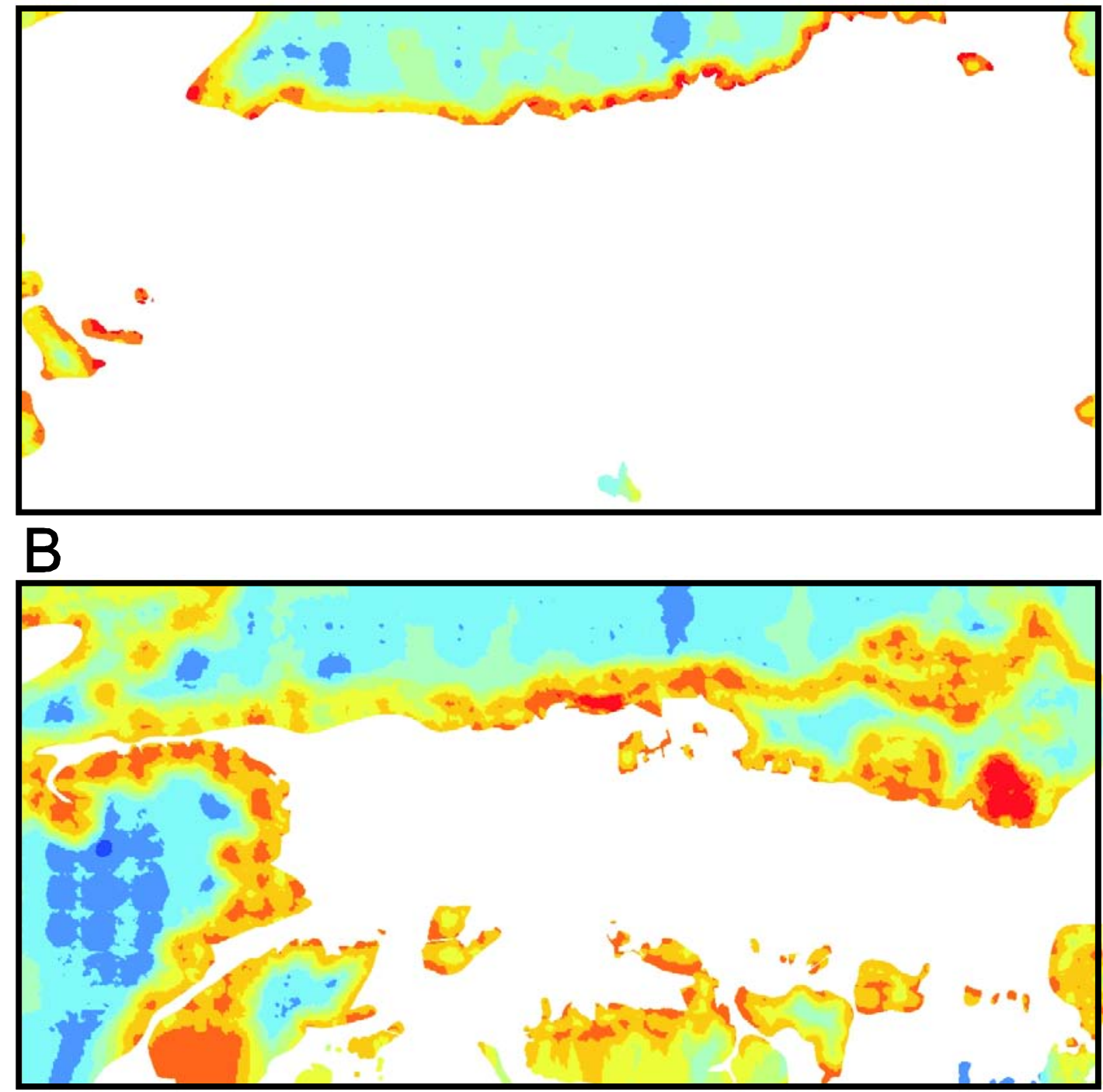

C

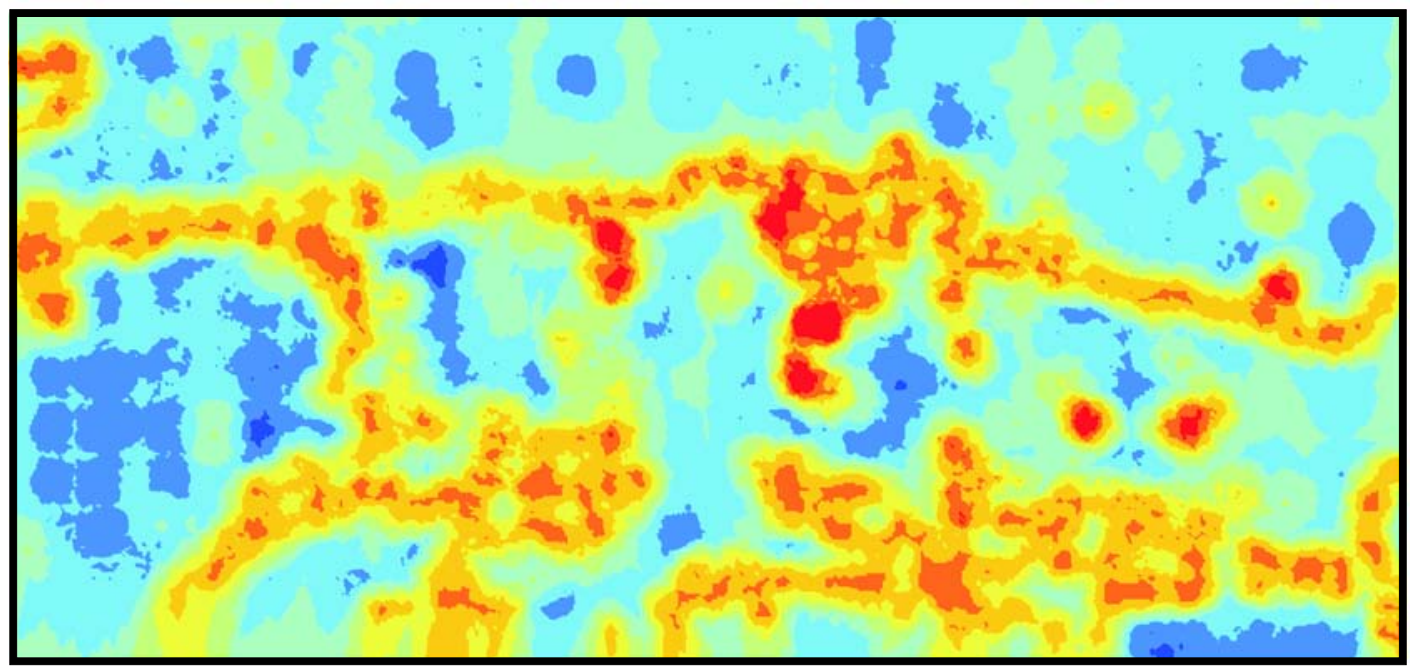

Figure 13. Grids displaying confidence data in the Thames Gateway region between Woolwich and Gravesend for a) London Clay Formation, b) Thanet Sand Formation and c) the Chalk Group. Colour variation from blue to red indicating a change from low to high confidence. 


\section{Figures}

\section{References}

Anon. 1995. The Thames Gateway Planning Framework. RPG9A. HMSO 77p

Anon. 1999. Code of practice for site investigation, BS5930. British Standard Institution, London, 204p

Anon. 2004. Geotechnical investigation and testing - Identification and classification of soil - Part 2: Principles for a classification (CEN ISO 14688-2:2004). British Standard Institution, London.

Baker G R, and Giles J. 2000. BGS Geoscience integrated database system : a repository for corporate data. In: Earthwise, vol 16. pp 12-13

Barclay W J, Ellison R A, and Northmore K J. 1990. A geological basis for land-use planning: Garforth-CastlefordPontefract : 1:10 000 sheets SE42NW,NE, SW, SE, SE43SW and SE52SW, parts of 1:50 000 geological sheets 70 (Leeds) and 78 (Wakefield): British Geological Survey, Technical Report WA/90/3. 111p

Berry, F.G., 1979. Late Quaternary scour hollows and related features in central London. Quarterly Journal of Engineering geology, 12: 9-29.

Bobrowsky, P T. 2002. Geoenvironmental mapping: methods, theory and practice. Lisse: AA Balkema.

Bowie R. 2005. Creating a digital landslide. Geoscientist 15 (3): 4-7

Bradshaw J, Caiger N, Halpin M, Le Gear R, Pearce A, Pearman H, Reeve T and Sowan P. 1991. Kent and East Sussex Underground. Meresborough Books. 128p

Bristow R, Mortimore RN and Wood C J. 1997. Lithostratigraphy for mapping the Chalk of southern England. Proceedings of the Geologists Association 109: 293-315

Cave, M R, \& Wood, B. 2003. Approaches to the Measurement of uncertainty in geoscience data modelling:. British Geological Survey Internal Report, IR/02/068. pp 38

Chernick, M R. 1999. Bootstrap Methods, A practitioner's guide. Wiley Series in Probability and Statistics.

Communities and Local Government. 2006a. Planning Policy Statement 25: Development and Flood Risk. Full regulatory Impact Assessment. Communities and Local Government Publications. 26 p.

Communities and local Government. 2006b. Planning Policy Statement 9: Biodiversity and geological conservation. Final Regulatory Impact Assessment. DCLG publications. 10 p

Clarke S M. 2004. Confidence in geological interpretation. A methodology for evaluating uncertainty in common two and three-dimensional representations of subsurface geology. British Geological Survey Internal Report, IR/04/164. pp 29

Culshaw, M G and Ellison, R A. 2002. Geological maps: their importance in a user-driven digital age. In Van Roony, J L, \& Jermy, C A. (Editors), Proceedings of the $9^{\text {th }}$ International Association for Engineering Geology and the Environment Congress, Durban, 16-20 September 2002. Keynote Lectures and Extended Abstracts Volume, 25-51. Pretoria: South African 
Institute of Engineering and Environmental Geologists [ISBN 0-620-28560-5]. Also pages 67-92 on CD Rom [ISBN 0-62028559-1].

Culshaw M G. 2003. Bridging the gap between geoscience providers and the user community. In: Rosenbaum MS, Turner AK (eds) New paradigms in subsurface prediction, Lecture notes in earth sciences 99. Springer-Verlag, Berlin, pp 7-26

Culshaw M G. 2005. From concept towards reality: developing the attributed 3D model of the shallow subsurface. Quarterly Journal of Engineering Geolology and Hydrogeology, 38: 231-284.

Ellison, R A, McMillan, A A, and Lott, G K. 2002. Ground characterization of the urban environment: a guide to best practice. British Geological Survey Internal Report, IR/02/044.

Ellison, R A., Arrick, A, Strange, P J and Hennessey, C. 1998. Earth science information in support of major development initiatives. British Geological Survey Technical Report, WA/97/84.

Ellison R. 2004. Geology of London - special memoir for 1:50,000 geological sheets 256 (North London), 257 (Romford), 270 South London) and 271 (Dartford) (England and Wales), $114 \mathrm{p}$

Environment Agency. 1990. Rising groundwater levels in the Chalk-basal sands aquifer of the Central London basin - 1990. Unpublished report.

Environment Agency. 2004. Rising groundwater levels in the Chalk-basal sands aquifer of the Central London basin - May 2004. Unpublished report.

Evans R. 2003. Current themes, issues and challenges concerning the prediction of subsurface conditions. In: Rosenbaum MS, Turner AK (eds) New paradigms in subsurface prediction: characterisation of the shallow subsurface: implications for urban infrastructure and environmental assessment. Springer-Verlag, Düsseldorf, pp 359-378

Farrant A R. 2001. Karst development in southern English Chalk. In: Beck BF and Herring JG (eds) Geotechnical and Environmental applications of karst geology and hydrology. Swets and Zeitlinger pp77-82

Fookes P G. 1997. Geology for engineers: the geological model, prediction and performance. Q J Eng Geol 30: 293-424

Fookes P G, Baynes F G, Hutchinson J N. 2000. Total geological history: a model approach to the anticipation, observation and understanding of site conditions. Proceedings of the International Conference on Geotechnical and Geological Engineering, Melbourne, Australia, 1. Technomic publishing Co, Lancaster, Pennsylvania, USA: 370-460.

Forster A, Arrick M, Culshaw M G, Johnston M eds. 1995. A geological background for planning and development in Wigan. Technical Report WN/95/3. British Geological Survey. pp 151.

Forster, A, Lawrence, D J D, Highley, D E, Cheney, C S and Arrick A. 2004. Applied geological mapping for planning and development: an example from Wigan UK. Quarterly Journal of Engineering Geology and Hydrogeology, 37, 301-315.

Hack R, Orlic B, Ozmutlu S, Rengers N. 2006. Three and more dimensional modelling in geo-engineering. Bull Eng Geol Env 65:143-153

Hinze C, Sobisch H-G, Voss H-H (1999) Spatial modelling in geology and its practical use. Mathematische Geologie 4: 5160

Howland A.F. 2000. The history of the development of procedure for the rapid assessment of environmental conditions to aid the urban regeneration process at London Docklands. Engineering geology, 60, 117-125 
Jackson C R, Spink A E F (2004) User’s manual for the groundwater flow model ZOOMQ3D. British Geological Survey Internal Report, IR/04/140. pp 94

Jackson C R, Hughes AG, Bloomfield J P and Rutter H K (2004) Numerical modelling of groundwater flow in the Darent catchment and Swanscombe area Chalk aquifer. British Geological Survey Commissioned Report, CR/03/183C. pp 140.

Jackson I. 2004. Britain beneath our feet. In: British Geological Survey Occasional Publication No. 4, pp 114

Kessler H. and Mathers S. 2004. Maps to Models. Geoscientist, 14 (10) : 4-6

Kesslar, H., Mathers, S J \& Sobisch, H.-G. 2004. GSI3D: The software and methology to build near surface 3-D geological models. BGS Internal Report, IR/04/029.

Kindlarski E. 1984. Ishikawa diagrams for problem -solving. Quality Progress 17 (12): 26-30

Lake R D, Northmore K J, Dean MT and Tragheim D G. 1992. Leeds : a geological background for planning and development : 1:10000 sheets SE23NW, NE, SE and SE33NW, NE, SW, SE : parts of 1:50000 geological sheets 69 (Bradford), 70 (Leeds), 77 (Huddersfield) and 78 (Wakefield). British Geological Survey, Onshore Geology Series, Technical Report WA/92/001. pp 83

Lelliott M.R., Bridge D.M., Kesslar H., Price S.J. and Seymour K.J., 2006. The application of 3D geological modelling to aquifer recharge assessments in an urban environment. Quarterly Journal of Engineering Geology and Hydrogeology, 39: 293-302.

Lewis M, Cheney C and Ó Dochartaigh. (In press). The National Assessment of permeability indices. British Geological Survey Report.

McKirdy, A. P., Thompson, A. \& Poole, J. 1998. Dissemination of information on the earth sciences to planners and other decision-makers. In Bennett, M R, and Doyle, P. (eds), Issues in environmental geology: a British perspective. (Oxford: The Geological Society of London.)

ODPM. 2004. Planning Policy Statement 23: Planning and Pollution control. pp20

Pasak J and Ryber J. 1961. Die Darstellung ingeneieurgeologischerVerhaltnisse in der Karte 1:25 000. Zeitschrift für Angewandte Geologie 7 (3): 36-139.

Powell J H, Glover BW and Waters C N. 1992 A geological background for planning and development in the 'Black Country': British Geological Survey, Onshore Geology Series, Technical Report WA/92/33. pp 79

Roberts GD. 1964. Investigation versus exploration. Bull Assoc Eng Geol 1(2): 37-53.

Rosenbaum M S. 2003. Characterisation of the shallow subsurface: implications for urban infrastructure and environmental assessment. In: Rosenbaum MS, Turner AK (eds) New paradigms in subsurface prediction, Lecture notes in earth sciences 99. Springer-Verlag, Berlin, pp 3-6

Royse K R, Entwisle D, Price S, Terrington R. 2006a. Geoscience Solutions for the Thames Gateway. IAEG2006 Engineering geology for tomorrow’s cities. 1- 109: pp 9

Royse K R, Entwisle D, Price S, Terrington R, Venus J. 2006b. Gateway to Olympic success. Geoscientist 16(5): 4-10 Shepard, D. 1968. A two-dimensional interpolation function for irregularly-spaced data, Proc. 23rd National Conference ACM, ACM, 517-524. 
Smith A and Ellison RA. 1999. Applied geological maps for planning and development: a review of examples from England and Wales 1983 to 1996. Q J Eng Geol 32: S1-S44

Sobisch H-G. 2000. Ein difitles raeumliches Modell des Quartaers der GK25 Blatt 3508 Nordhorn auf der Basis vernetzer Profilschnitte. Shaker Verlag, Aachen.

Strange P.J, Booth S.J and Ellison R.A. 1998. Development of 'rockhead' computer -generated geological models to assist geohazards prediction in London. In Maund J.G. and Eddleston M. (eds) Geohazards in engineering geology. Geological Society Engineering geology special publication 15, 409-414

Thompson A, Hine PD, Greif JR and Poole J S. 1998. Environmental geology in Land Use and Planning: Advice for Planners and developers. Report to the Department of the Environment.

Turner A K. 2003. Putting the user first: implications for subsurface characterisation. In: Rosenbaum MS, Turner AK (eds) New paradigms in subsurface prediction, Lecture notes in earth sciences 99. Springer - Verlag, Berlin, pp 61-83

Turner A K. 2006. Challenges and trends for geological modelling and visualisation. Bulletin of Engineering Geology and the Environment 65:109 - 127

Water Resources Board. 1972. The hydrogeology of the London Basin. Unpublished report.

\section{Figure Legends}

Fig. 1. Geological Map of London and the surrounding area

Fig. 2. Flow diagram showing the process of building and applications of the 3D attributed geological model

Fig.3. 3D geological model building work flow in GIS3D (after Kessler and Mathers, 2004)

Fig. 4. Box and Whisker plot of standard penetration test results for the terrace gravels in part of the Thames Gateway area. Where BHT = Boyne Hill Gravel Formation; LHT= Lynch Hill Gravel Formation, TPGR = Taplow Gravel Formation and RTDU = Kempton Park and Shepperton Gravel formations

Fig. 5. 3D block model of the engineering geological classification of the area between Dartford and Thurrock (see Table 1 for key).

Fig. 6. Exploded volume model illustrating the EA’s WFD aquifer classification scheme

Fig. 7. Engineering characteristics at ground surface, and $1 \mathrm{~m}, 5 \mathrm{~m}$ and $10 \mathrm{~m}$ below ground surface. See Table 5 for key.

Fig. 8. Cross-section showing the variation of SPT values within the Thames Gravels and Chalk within grid square TQ57NW.

Fig. 9. Temperature and conductivity log for borehole TQ57SW29 (GR 551800,0174800).

Fig. 10. 3D geological model of the Lower Lea Valley, Stratford, London with automatically generated geological, and engineering geological cross-sections through the middle of the Lower Lea Valley

Fig. 11. Contour map of the thickness of the alluvium between Bexley and Tilbury displayed in ArcGIS generated from the 3D geological Model. 
Fig. 12. Intersection of simulated groundwater table for February 1995 (blue) with DTM within the West Thurrock area.

Fig. 13. Grids displaying confidence data in the Thames Gateway region between Woolwich and Gravesend for a) London Clay Formation, b) Thanet Sand Formation and c) the Chalk Group. Colour variation from blue to red indicating a change from low to high confidence.

\section{Table Titles}

Table 1. Engineering geological character of the surface geology in the Thames Gateway area. 
